\title{
In situ physical and chemical characterisation of the Eyjafjallajökull aerosol plume in the free troposphere over Italy
}

\author{
S. Sandrini ${ }^{1}$, L. Giulianelli ${ }^{1}$, S. Decesari ${ }^{1}$, S. Fuzzi ${ }^{1}$, P. Cristofanelli ${ }^{1}$, A. Marinoni ${ }^{1}$, P. Bonasoni ${ }^{1}$, M. Chiari $^{2}$, \\ G. Calzolai ${ }^{2}$, S. Canepari ${ }^{3}$, C. Perrino ${ }^{4}$, and M. C. Facchini ${ }^{1}$ \\ ${ }^{1}$ Institute of Atmospheric Sciences and Climate, National Research Council, Bologna, 40129, Italy \\ ${ }^{2}$ Italian National Institute for Nuclear Physics, Florence section, Sesto Fiorentino, 50019, Italy \\ ${ }^{3}$ University of Rome "La Sapienza", Chemistry Department, Rome, 00185, Italy \\ ${ }^{4}$ C.N.R. Institute of Atmospheric Pollution, Monterotondo St., Rome, 00015, Italy
}

Correspondence to: S. Sandrini (s.sandrini@isac.cnr.it)

Received: 21 May 2013 - Published in Atmos. Chem. Phys. Discuss.: 2 August 2013

Revised: 29 November 2013 - Accepted: 17 December 2013 - Published: 29 January 2014

\begin{abstract}
Continuous measurements of physical and chemical properties at the Mt. Cimone (Italy) GAW-WMO (Global Atmosphere Watch, World Meteorological Organization) Global Station (2165 m a.s.l.) have allowed the detection of the volcanic aerosol plume resulting from the Eyjafjallajökull (Iceland) eruption of spring 2010. The event affected the Mt. Cimone site after a transport over a distance of more than $3000 \mathrm{~km}$. Two main transport episodes were detected during the eruption period, showing a volcanic fingerprint discernible against the free tropospheric background conditions typical of the site, the first from April 19 to 21 and the second from 18 to 20 May 2010. This paper reports the modification of aerosol characteristics observed during the two episodes, both characterised by an abrupt increase in fine and, especially, coarse mode particle number.

Analysis of major, minor and trace elements by different analytical techniques (ionic chromatography, particle induced X-ray emission-particle induced gamma-ray emission (PIXE-PIGE) and inductively coupled plasma mass spectrometry (ICP-MS)) were performed on aerosols collected by ground-level discrete sampling. The resulting database allows the characterisation of aerosol chemical composition during the volcanic plume transport and in background conditions. During the passage of the volcanic plume, the fine fraction was dominated by sulphates, denoting the secondary origin of this mode, mainly resulting from in-plume oxidation of volcanic $\mathrm{SO}_{2}$. By contrast, the coarse fraction was characterised by increased concentration of numerous elements of crustal origin, such as $\mathrm{Fe}, \mathrm{Ti}, \mathrm{Mn}, \mathrm{Ca}, \mathrm{Na}$, and $\mathrm{Mg}$,
\end{abstract}

which enter the composition of silicate minerals. Data analysis of selected elements (Ti, Al, Fe, Mn) allowed the estimation of the volcanic plume's contribution to total $\mathrm{PM}_{10}$, resulting in a local enhancement of up to $9.5 \mathrm{\mu g} \mathrm{m}^{-3}$, i.e. $40 \%$ of total $\mathrm{PM}_{10}$ on $18 \mathrm{May}$, which was the most intense of the two episodes. These results appear significant, especially in light of the huge distance of Mt. Cimone from the source, confirming the widespread diffusion of the Eyjafjallajökull ashes over Europe.

\section{Introduction}

Volcanoes are highly active sources of aerosols and gases, hence having an impact on the atmospheric radiative budget. The effects can be both direct, by backscattering and absorption of solar radiation, as well as indirect, by increasing the condensation nuclei number and ultimately affecting cloud properties and lifetime. Volcanic emissions mainly consist of two components: (1) primary solid and liquid particles, forming through magma disintegration and erosion of the conduit wall, and (2) gaseous compounds $\left(\mathrm{SO}_{2}, \mathrm{H}_{2} \mathrm{~S}, \mathrm{HCl}\right.$ and $\mathrm{HF}$ ), which are potential precursors of secondary aerosol and mainly represented by sulphate particles produced by gas- or cloud-phase oxidation of $\mathrm{SO}_{2}$. Volcanic aerosol generally exhibits multi-mode size distributions due to its multiple formation processes, with fragmented magma and erosion of particles from the vent walls in the coarse fraction $(>1 \mu \mathrm{m})$ and finer particles resulting from the condensation of volatiles 
and gas-phase reaction products in the accumulation mode (Mather et al., 2003; Mather, 2008).

Volcanic particles can undergo long-range transport in the atmosphere, during which their size distribution evolves due to the settling of the largest particles and condensational growth of particles in the fine and ultrafine fractions. In addition, the aerosol residence in the atmosphere of several days modifies the original chemical composition following in-plume chemical processing. Hence, the longer the distance from the source, the more difficult it is to distinguish an unequivocal volcanic signature. Eventually, the particle concentration decreases until it is no longer distinguishable from the background atmospheric concentration. At long distances from the source, volcanic plumes can be better identified at high-altitude sites, where the masking effect of background particles forming in the planetary boundary layer (PBL) is reduced.

Research on volcanic aerosol was in the past mainly oriented towards coarse particles, while the fine fraction received less attention. Currently, however, interest is focusing on the joint investigation of gases, fine aerosols and coarse aerosols in order to understand the spatial distribution of the different types of compounds produced by the eruption and their transformation during transport, since a significant part takes the form of fine particles, which are responsible for severe health effects (Pope, 2000).

With its tropospheric lifetime of several days, $\mathrm{SO}_{2}$ is an excellent tracer of long-range transport of volcanic emissions, especially in areas not strongly influenced by anthropogenic emissions (Flentje et al., 2010). During transport, sulphuric acid is formed by gas-phase and aqueousphase reactions and by heterogeneous reactions on the surface of solids (Mather et al., 2006). $\mathrm{H}_{2} \mathrm{SO}_{4}$ is taken up very efficiently by pre-existing aerosol particles and cloud droplets. Alternatively, it can nucleate to form new particles, especially in conditions of low condensation sinks (von Glasow, 2009). Volcanic plumes are therefore normally characterised by increased concentrations of gaseous $\mathrm{SO}_{2}$ and sulphate, a chemical feature that is sometimes observed even at long distances despite the widespread presence of anthropogenic emissions. Super-micrometric particle number concentrations in the presence of volcanic plumes are generally enhanced due to primary ash particles (coarse fraction). Occasionally, new-particle formation in the ultrafine size range also occurs in volcanic plumes (Flentje et al., 2010).

Volcanic aerosols are considerably enriched in many trace elements, including alkali, alkali-earth, transition, and heavy metals, which can either originate via magma volatilisation or (in the case of soluble species) from acid leaching of the vent wall rock or silicate ash particles (Mather et al., 2003). Aerosols within volcanic plumes may be highly enriched in these elements relative to levels in either crustal material or ash deposited in the immediate vicinity of the eruption (Symonds et al., 1987).
Apart from cataclysmal eruptions, which affect climate on a global scale, moderate eruptions and/or quiescent degassing can have considerable local effects. However, their impact is spatially and temporally inhomogeneous, given the turbulent nature of the lower troposphere where residence times would typically be less than 1 week.

The Icelandic volcano Eyjafjallajökull $\left(63^{\circ} 38^{\prime} \mathrm{N}\right.$, $19^{\circ} 36^{\prime} \mathrm{W}, 1660 \mathrm{~m}$ a.s.1.) erupted on 20 March 2010, after a relatively silent period of nearly $190 \mathrm{yr}$. A major outbreak of the central crater under the covering ice cap started on April 14 and continued until 24 May, ejecting a very large amount of gases and fine ashes into the atmosphere. The eruption was considered of moderate magnitude, but emissions remained in the troposphere (up to $10 \mathrm{~km}$ ) for days and affected highly populated central Europe, inducing disruption of air traffic for several days. Meanwhile, several ground-based instruments and stations were able to monitor the volcanic plume, representing a unique opportunity for the study of aged volcanic aerosol.

The dynamics of the eruption have been extensively described in the literature in terms of ground-based remote sensing and satellite observations, highlighting the optical properties of the volcanic plume (e.g. Pappalardo et al., 2013; Ansmann et al., 2010; Flentje et al., 2010; Madonna et al., 2010; Mona et al., 2012; Schumann et al., 2011; Stohl et al., 2011; Schäfer et al., 2011). However, the chemical composition of aerosol from airborne measurements (Schumann et al., 2011; Bukowiecki et al., 2011; Rauthe-Schöch et al., 2012; Andersson et al., 2013) or from ground-level samplings (Revuelta et al., 2012; Schleicher et al., 2012; Lettino et al., 2012; Beeston et al., 2012; Bukowiecki et al., 2011; Colette et al., 2011) were derived in a few cases only.

Owing to its remoteness from intense pollution sources, Mt. Cimone (see site description below) in northern Italy offers a unique opportunity to observe the influence of airborne particulate sources, usually overshadowed by local sources at ground-level locations. A comprehensive suite of aerosol measurements was performed at this site during the eruption period. Such measurements, which allowed the detection of the volcanic plume transit first from 19 to 21 April and again between 18 and 20 May 2010, therefore add some unique observations to the multitude of different measurements performed in various parts of Europe during the eruption.

The objective of this study is twofold: (1) to characterise the long-range transported volcanic plume that reached the Italian station of Mt. Cimone from 19 April to 20 May 2010, through the continuous monitoring of physical parameters (size distribution, scattering, absorption, particle mass) and off-line chemical analysis; and (2) to quantify the actual contribution of volcanic particles on the whole local aerosol burden, at a distance of more than $3000 \mathrm{~km}$ from the eruption, which will include a review of similar measurements obtained in other parts of Europe from ground-based stations and from model calculations. 


\section{Experimental}

\subsection{Sampling site}

Mt. Cimone (CMN, $2165 \mathrm{~m}$ a.s.l.) is the highest summit of the Italian northern Apennines $(44.11 \mathrm{~N}, 10.42 \mathrm{E}$, $2165 \mathrm{~m}$ a.s.1.). This sampling site, with its $360^{\circ}$ free horizon, can be considered for most of the year representative of the southern Europe free troposphere (Bonasoni et al., 2000; Fischer et al., 2003). Only during fair weather days in the warm months CMN is influenced by thermally induced injections of pollutants from the PBL (Cristofanelli et al., 2009). CMN therefore constitutes a suitable location for investigating the influence of long-range transport of air masses, which are potentially able to modify the tropospheric background conditions of the Mediterranean basin (Marinoni et al., 2008).

\subsection{Monitoring of aerosol physical parameters}

In this work we analyse the aerosol particle size distribution, equivalent $\mathrm{BC}$ concentration and scattering coefficient at $525 \mathrm{~nm}$, together with meteorological parameters (wind speed and direction) and surface ozone concentrations, which are continuously monitored at CMN.

The multi-angle absorption photometer (MAAP) (Thermo Scientific) provides equivalent black carbon concentrations (eq BC) by measuring the aerosol absorption coefficient $b_{\mathrm{abs}}$ at $637 \mathrm{~nm}$ (Petzold and Schönlinner, 2004). Mass absorption efficiency set by default on MAAP and recommended by Petzold et al. (2002) is $6.5 \mathrm{~m}^{2} \mathrm{~g}^{-1}$. The scattering coefficient $b_{\text {sca }}$ at $525 \mathrm{~nm}$ is measured by an integrating nephelometer (M9003, Ecotech), whose data are adjusted to standard temperature and pressure conditions $\left(0^{\circ} \mathrm{C} ; 1000 \mathrm{hPa}\right)$. Fine particle concentrations are measured by a condensation particle counter (CPC) (3772, Thermo Systems Inc.), which detects airborne particles with diameter ranging from $10 \mathrm{~nm}$ (counting efficiency $>50 \%$ ) to $3 \mu \mathrm{m}$, over a concentration range from 0 to $10^{4}$ particles $\mathrm{cm}^{-3}$.

For the continuous size distribution measurements, an optical particle counter (OPC) (1.108, GRIMM) and a differential mobility particle sizer (DMPS) are deployed, both connected to a total aerosol sampling head. The OPC measures concentration and size distribution of particles with optical diameter between 0.30 and $20 \mu \mathrm{m}$ in 15 -size bins. According to the specifications, the reproducibility of the OPC in particle counting is $\pm 2 \%$ (Putaud et al., 2004). These measurements permit the determination of a fine $\left(0.3 \mu \mathrm{m} \leq D_{\mathrm{p}} \leq 1 \mu \mathrm{m}\right)$ and coarse mode $\left(1 \mu \mathrm{m} \leq D_{\mathrm{p}} \leq 20 \mu \mathrm{m}\right)$ aerosol fraction. As described in detail by Bukowiecki et al. (2011), aerosol measurements performed with a polystyrene latex (PSL)-calibrated OPC will result in a diameter shift of the actual size distribution due to the different refractive indices of volcanic ash. This results in a larger uncertainty in OPC measurements. The DMPS measurements were within $10 \%$ for the size range $20-200 \mathrm{~nm}$ against a reference system under controlled laboratory conditions, while for sizes up to $500 \mathrm{~nm}$ the deviation was up to $25 \%$ (Wiedensohler et al., 2012).

\subsection{Chemical analyses}

Within the EU-funded EUSAAR (European Supersites for Atmospheric Aerosol Research) and ACTRIS (Aerosols, Clouds and Trace gases Research InfraStructure network) projects, background aerosol chemical composition has been continuously measured at CMN since February 2009. Samples for off-line chemical analyses are collected by a dichotomous virtual impactor (M310, Universal Air Sampler TM), which allows the collection of the fine $\left(\mathrm{PM}_{1}\right)$ and coarse $\left(\mathrm{PM}_{1}-\mathrm{PM}_{10}\right)$ fraction of particulate matter at a flow rate of $300 \mathrm{~L} \mathrm{~min}^{-1}$. The filters used for the collection of the two aerosol fractions are pre-washed and pre-baked quartz-fibre filters (Whatman microfibre binder free QMA, $9 \mathrm{~cm}$ size, for the fine fraction and Whatman quartz microfibre filters QMA for the coarse fraction). Except for special intensive field campaigns, such as the one described in this paper, one nocturnal sample is collected per week (from 22:00 to 06:00 LT, $8 \mathrm{~h}$ sampling time). The sample is analysed for total carbon (TC), and water-soluble organic carbon (WSOC) by a multianalyser (multi N/C 2100, Analytik Jena), equipped with a non-dispersive infrared (NDIR) detector, while ionic chromatography is employed for major water-soluble inorganic anions $\left(\mathrm{Cl}^{-} ; \mathrm{NO}_{3}^{-} ; \mathrm{SO}_{4}^{2-}\right)$, cations $\left(\mathrm{Na}^{+} ; \mathrm{NH}_{4}^{+} ; \mathrm{K}^{+} ; \mathrm{Mg}^{2+}\right.$; $\mathrm{Ca}^{2+}$ ) and organic acids. For this purpose two Dionex ICS2000 are dedicated respectively to anions (Dionex IonPac AS11 separation column with IonPac AG11 guard column, mobile phase $\mathrm{KOH}$ autogenerated with gradient program) and cations (Dionex IonPac AS16 separation column with IonPac AG16 guard column, mobile phase methanesulfonic acid autogenerated with isocratic elution).

The choice of nocturnal sampling is oriented towards catching the free troposphere conditions both in the cold and in the warm season because occasionally, especially around noontime during summer days, the site experiences maxima in aerosol number and black carbon (BC) concentrations due to enhanced vertical transport from lower elevations and mountain breeze wind regime (Cristofanelli et al., 2007; Marinoni et al., 2008; Carbone et al., 2010). Based on transport forecasts, indicating the possible arrival of the volcanic plume, from 20 April the routine sampling was intensified, with the collection of 11 samples (9 nocturnal and 2 diurnal) covering the period from 20 April to 19 May 2010.

As volcanic particulate emissions are primarily composed of non-carbonaceous and insoluble material, often characterised by the presence of trace elements normally not found in ambient aerosol, such filters were analysed for additional chemical parameters: the total content of elements $\mathrm{Na}, \mathrm{Mg}$, $\mathrm{Al}, \mathrm{S}, \mathrm{K}, \mathrm{Ca}, \mathrm{Ti}, \mathrm{Cr}, \mathrm{Mn}, \mathrm{Fe}, \mathrm{Ni}, \mathrm{Cu}, \mathrm{Zn}, \mathrm{As}, \mathrm{Br}, \mathrm{Sr}, \mathrm{Y}, \mathrm{Zr}$, Mo and $\mathrm{Pb}$ was determined by quantitative multi-elemental analysis using particle induced X-ray emission-particle induced 
gamma-ray emission (PIXE-PIGE). PIXE-PIGE analysis was performed at the $3 \mathrm{MV}$ Tandetron accelerator in Florence, with a $5 \mathrm{nA} 3 \mathrm{MeV}$ proton beam using the external beam setup described in Calzolai et al. (2006). This technique represents a very powerful tool for environmental and geological studies and has been successfully applied in the characterisation of volcanic emissions (Koltay et al., 1999). PIXE provides multi-elemental analysis (elements with atomic number larger than 10) of samples with high sensitivity and non-destructivity, hence allowing the subsequent application of other techniques. Nevertheless, PIXE may underestimate the concentrations of the light elements due to the absorption of the low-energy X-rays both inside the particles in the coarse fraction and in the quartz fibre filter matrix itself. PIGE exploits the much more energetic $\gamma$-ray radiation and therefore it does not suffer from the aforementioned absorption problems (Calzolai et al., 2010). However, a quantitative PIGE analysis may be performed only for selected elements; in the present case, PIGE measurements of $\mathrm{Al}$ were performed simultaneously with PIXE in order to estimate attenuation correction factors for an accurate quantification of the lighter elements (Na to Ti) (Formenti et al., 2010).

A series of metals and metalloids $(\mathrm{Li}, \mathrm{B}, \mathrm{Na}, \mathrm{Mg}, \mathrm{Al}, \mathrm{P}, \mathrm{Ca}$, $\mathrm{Cr}, \mathrm{Mn}, \mathrm{Co}, \mathrm{As}, \mathrm{Mo}, \mathrm{Cd}, \mathrm{Sb}, \mathrm{Cs}, \mathrm{Ba}, \mathrm{La}, \mathrm{Ce}, \mathrm{W}, \mathrm{Tl}, \mathrm{Pb}$ and $\mathrm{U}$ ) extracted by acetate buffer solution at $\mathrm{pH} 4.5$ was analysed by inductively coupled plasma mass spectroscopy (ICP-MS) (820-MS, Varian, Australia), according to the method proposed by Canepari et al. (2006). This soluble fraction, compared to the total element determination, provides more information about the environmental and biological availability of the element and allows obtaining a higher selectivity as source tracer (Canepari et al., 2010), the soluble fraction being mostly associated with combustion sources and the insoluble one to crustal contributions. Finally, organic carbon (OC) and elemental carbon (EC) were analysed by a thermooptical transmission analyser (Sunset Laboratory Inc., OR, USA) using a NIOSH (National Institute of Occupational Safety and Health) quartz thermal protocol (Perrino et al., 2007).

Since filters are subjected to both water soluble organic carbon and inorganic ions determination throughout the year, measurements of these parameters before and after the volcanic transport events were available for comparison with the collected volcanic aerosol plume. Trace elements from PIXE-PIGE and ICP-MS, instead, represent quite new data for CMN. Hence, no comparisons with background conditions at the same site are possible, with the exception of some measurements performed by PIXE-PIGE in August 2007 during a Saharan dust transport episode (Cristofanelli et al., 2009). Other measurements of metals and trace elements had been performed during a summer campaign in 2004 by energy dispersive X-ray fluorescence (ED-XRF) (Marenco et al., 2006), and these data can be used as reference, although season and analytical techniques were different.

\subsection{HYSPLIT 3-D back trajectories}

Using the HYSPLIT (Hybrid Single-Particle Lagrangian Integrated Trajectory) model, $144 \mathrm{~h}$ 3-D air-mass backtrajectories ensembles were calculated to describe the airmass circulation and origin that affected $\mathrm{CMN}$ during the Eyjafjallajökull events (Draxler and Rolph, 2013). The model calculations were based on the Global Data Assimilation System (GDAS) meteorological field produced by the US National Center for Environmental Prediction (NCEP) with a horizontal resolution of $1^{\circ} \times 1^{\circ}$. For every point along the trajectory (time resolution: $1 \mathrm{~h}$ ), the model provides the geographic location and altitude (or pressure level) of the air parcel. Sub-grid scale processes like convection and turbulent diffusion are not represented by HYSPLIT back trajectories. To compensate partially for these uncertainties, every $6 \mathrm{~h}$ starting from 1 April (00:00 UTC) to 30 May 2010 (00:00 UTC), an ensemble of seven back trajectories was calculated, ending at the $\mathrm{CMN}$ location $\left( \pm 0.5^{\circ}\right.$ in latitude/longitude and $\pm 250 \mathrm{~m}$ in altitude).

\section{Results and discussion}

\subsection{Plume transport towards northern Italy and data overview}

The Eyjafjallajökull eruption entered its explosive phase on 14 April and continued until 24 May 2010, with two main phases of intense ash and gas emission defined as 1421 April and 1-18 May (Stohl et al., 2011). During the eruption, persistent north-westerly winds over Iceland favoured the spread of the volcanic plume south-eastwards, resulting in the dispersion of ashes over a large part of Europe at about 4-9 km above ground (Emeis et al., 2011; O'Dowd et al., 2012).

Remote sensing systems already observed the plume in the free troposphere over Europe on 16 April at an altitude of 3-6 km, but only on the afternoon of 17 April did intense vertical mixing and advection favour the entrainment of the volcanic material down to the ground in southern Germany (Flentje et al., 2010). Subsequently, on reaching the southernmost part of Europe, the air mass was deflected both east and west, with its presence observed over the Alps (Bukowiecki et al., 2011; Schäfer et al., 2011; Trickl et al., 2013). The transport to the south during this first approach of the plume was almost completely blocked by the Alps and by a lowpressure zone over northern Italy (Pappalardo et al., 2013; Trickl et al., 2013). Thus, the air mass resided over central Europe for several days, until 19 April when a redistribution of aged volcanic aerosol occurred from west to east and from north to south, at which time the plume was observed over Italy for the first time (Madonna et al., 2010; Lettino et al., 2012; Rossini et al., 2012; Belosi et al., 2011; Campanelli et al., 2012; Perrone et al., 2012). These changes in weather 

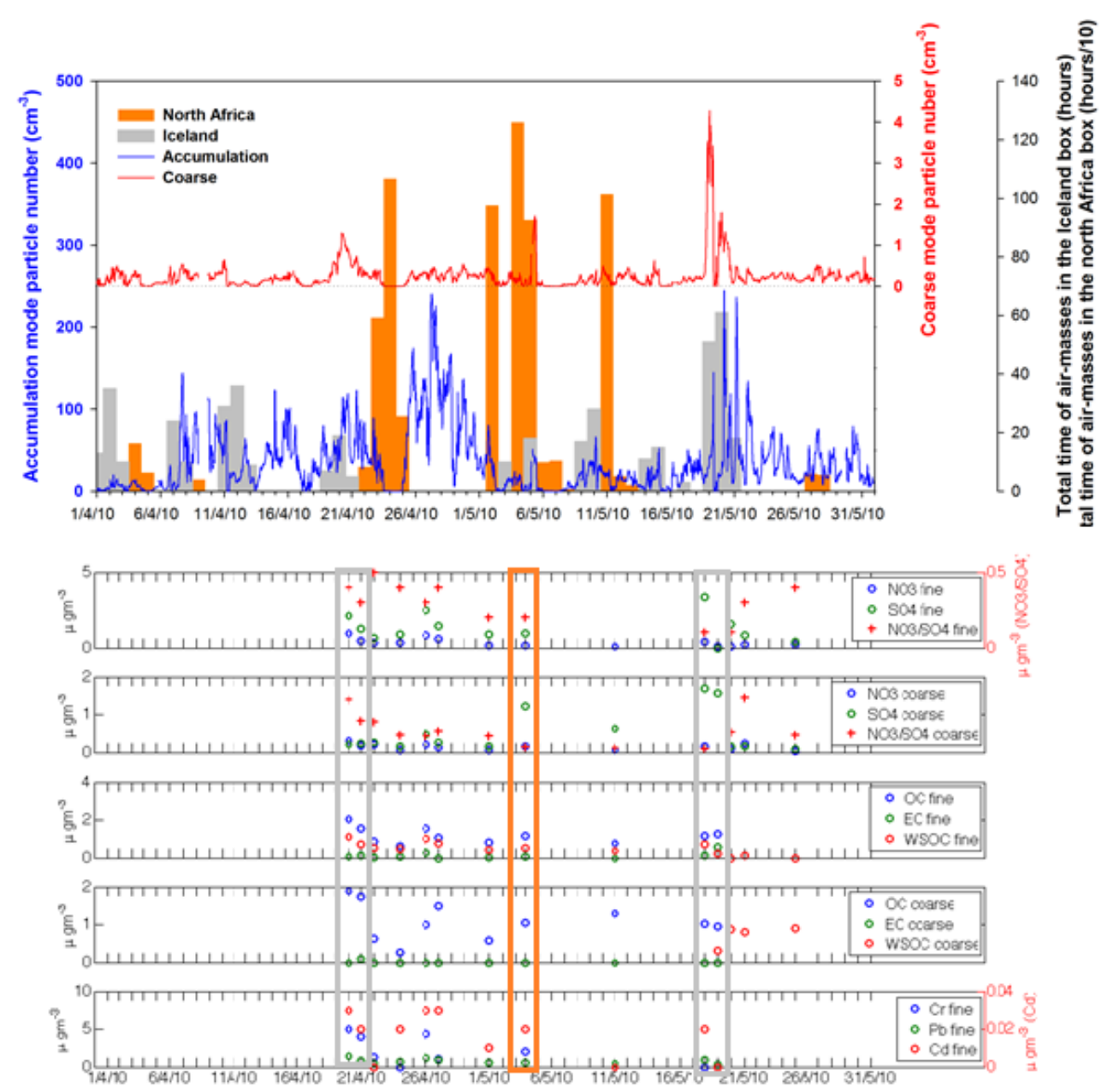

Fig. 1. (a) Particle number concentration recorded at CMN from 1 April to 31 May 2010 measured by OPC (0.3-20 $\mu \mathrm{m})$, separately for the accumulation mode $(<1 \mu \mathrm{m})$ and coarse mode $(>1 \mu \mathrm{m})$. The vertical bars denote the daily total number of back-trajectory points falling within the "Iceland" (grey) and the north Africa (orange) geographical boxes. (b) Temporal evolution of sulphate, nitrate, $\mathrm{NO}_{3} / \mathrm{SO}_{4}$ ratio, OC, EC and WSOC, separately for the fine and coarse mode, and $\mathrm{Cr}, \mathrm{Pb}$ and $\mathrm{Cd}$ in the fine fraction.

patterns were also discernible at CMN, where wind direction turned from northerly (on 17 April) to southerly (on 18 April) and eventually to northerly (on 19 April) (Fig. 3).

New significant eruptions occurred on 4-9 May and 1419 May. The first of these events mainly influenced western Europe, from Great Britain to the Iberian Peninsula (Pappalardo et al., 2013), while the second travelled over Ireland (O'Dowd et al., 2012) and Great Britain and reached central Europe (Bukowiecki et al., 2011; Hervo et al., 2012). Volcanic layers were observed in the central and eastern Mediterranean area, including Greece and Turkey, in the days from 18 to 22 May (Balis et al., 2010; Papayannis et al., 2012).

The HYSPLIT back trajectories were analysed on a daily basis to establish a possible source-receptor relationship between the Eyjafjallajökull eruption and the atmospheric compounds variability observed at CMN. In particular, for each day from 1 April to 31 May 2010, evaluations were made of the total number of back-trajectory points falling within the geographical box $62.5-65.5^{\circ} \mathrm{N},-21.5-17.5^{\circ} \mathrm{E}$, roughly corresponding to Iceland's location (hereinafter denoted as the "Iceland" box). The choice of this rather large geographical box was made in order to take into account the possible uncertainty associated with back-trajectory calculation, reaching $15-30 \%$ of the travel distance from the end point (Draxler and Rolph, 2013). As suggested by this analysis (Fig. 1a), air masses possibly originating from the Iceland region, and thus affected by the Eyjafjallajökull eruption, were present at CMN on several days. In particular, two major episodes were probably related to the volcanic plume transport: 19-21 April and 18-20 May 2010. During these two events, data clearly show the modification of the typical regional background aerosol at the site, normally characterised by only few coarse mode particles per $\mathrm{cm}^{3}$. In both cases, the instruments recorded an enhanced particle number concentration, with the coarse mode greatly above the typical 
background (Fig. 1), as well as an increase in the scattering and absorption coefficients (Figs. 3 and 4).

A further significant increase in particle number in the coarse and accumulation modes occurred on 5 May 2010 in the presence of air masses from Iceland. However, on this day, air masses originating from north Africa (roughly $10-35^{\circ} \mathrm{N} ; 15^{\circ} \mathrm{W}-30^{\circ} \mathrm{E}$ ) were also present at CMN, resulting in a superimposed contribution of Saharan mineral dust (Fig. 1a). Again, accumulation mode particles showed a marked increase on 26 April, but on this occasion no simultaneous build-up of coarse particles was observed. This was attributed to the transport of polluted air from the PBL, following a period of high pressure.

The air masses originating from Iceland and passing over CMN between April and May travelled for about 5 days over a distance of more than $3000 \mathrm{~km}$. For the typical ash collected during the explosive phase of the eruption near the source, diameter peaked at approximately $500 \mu \mathrm{m}$, with at least $20 \%$ of mass $<10 \mu \mathrm{m}$ (Gislason et al., 2011), therefore able to stay airborne while being transported over long distance. Far from the source, aircraft measurements over France between 19 and 22 April showed increased particle concentrations both in the submicronic $(\sim 100 \mathrm{~nm})$ and in supermicronic $(\sim 2 \mu \mathrm{m})$ modes in the PBL (Hervo et al., 2012 ). The following section provides a detailed description of the modifications in the aerosol size distribution and chemical composition at $\mathrm{CMN}$ during the two above-mentioned major transport events (Table 1).

\subsection{Case 1: 19-21 April 2010}

Starting from 05:00 (UTC+1) on 19 April 2010, an increase in coarse particle concentration was detected, from $0.09 \mathrm{~cm}^{-3}$ to $1.28 \mathrm{~cm}^{-3}$, on 20 April when the peak reached the maximum concentration. As shown in Fig. 3, the period of the aerosol peak concentration was mainly characterised by the presence of northerly winds (from NW to NE) at the measurement site. The effects of the volcanic plume transport on the coarse particle number at CMN persisted until 22 April. In parallel with the coarse aerosol particles, an increase in the submicron aerosol fraction was also observed with two maxima recorded, one on 19 April at 14:00 $\left(4543 \mathrm{~cm}^{-3}\right)$ and the second on 20 April at 16:00 $\left(3967 \mathrm{~cm}^{-3}\right)$. Such values are significantly higher than the typical concentrations usually observed at CMN, where the average concentration for the period 2008-2010 was $2486 \pm 165 \mathrm{~cm}^{-3}$ (Marinoni et al., 2008; Asmi et al., 2011). Meanwhile, the aerosol absorption coefficient (30 min average) increased from a value below the instrumental detection limit $\left(0.07 \mathrm{Mm}^{-1}\right)$ to a maximum of $6 \mathrm{Mm}^{-1}$, while the scattering coefficient increased from less than $20 \mathrm{Mm}^{-1}$ to a maximum of $80 \mathrm{Mm}^{-1}$ on 20-21 April (nephelometer detection limit $0.3 \mathrm{Mm}^{-1}$, as declared by the manufacturer) (Fig. 3). It is worth noting that, albeit over different ranges, all these atmospheric compounds showed the same temporal behaviour, suggesting the hypothesis that common processes or sources determined the occurrence of the observed peaks. The volcanic influence on the air mass is supported by the analysis of the HYSPLIT back trajectories, showing air masses coming from the Icelandic region with an average transport time of $104 \pm 26 \mathrm{~h}$ (Fig. 2). The volcanic signal during this transit was quite weak but still discernible in the atmospheric composition measurements at $\mathrm{CMN}$, though the plume was no longer visible from METEOSAT SEVIRI satellite imagery after the dilution undergone during the transport (Schäfer et al., 2011).

The air masses travelled at a rather low pressure level $(<700 \mathrm{hPa})$ and experienced fast downward transport over continental Europe, where mixing with regional PBL air masses probably occurred before reaching CMN (Fig. 2). The increase in the number of particles against concentrations prior to plume arrival (taking 17 April as reference) occurred in different proportions for the three particle modes: the coarse mode increase was by far the highest (> 200 times), and accumulation modes also increased (12 times), while the fine particle number concentration underwent a threefold increase only. Hence, the two orders of magnitude increase of the aerosol coarse fraction was the main evidence of volcanic ash advection.

In order to obtain a comprehensive view of the aerosol size distribution, OPC $\left(D_{\mathrm{p}, \text { opt }}>300 \mathrm{~nm}\right)$ and DMPS data $\left(10<D_{\mathrm{p}, \mathrm{mob}}<500 \mathrm{~nm}\right)$ were combined. Assuming particle sphericity, aerosol number distributions were converted to volume distributions $\left(\mathrm{d} V / \mathrm{d} \log \left(D_{\mathrm{p}}\right)\right)$, applying a correction on diameters in order to transform OPC diameter in mobility diameter, as in Khlystov et al. (2004). The size distributions observed during the two volcanic events are reported in Fig. 5, where they are compared to a clean-atmosphere situation just before the plume's arrival (17 April). On 20 April, a marked increase in accumulation mode particles was detected, peaking at $304 \mathrm{~nm}$. It was accompanied by the buildup of a coarse mode, which was almost invisible before air-mass arrival, peaking at about $2.5 \mu \mathrm{m}$. The fine sulphate concentration was moderately high in this first observation $\left(2.1 \mu \mathrm{g} \mathrm{m}^{-3}\right)$, about five times greater than the average value for the period April-May calculated over the years 2009$2011\left(0.41 \pm 0.90 \mu \mathrm{g} \mathrm{m}^{-3}\right)$ (Fig. 1b). It should be noted that the intensive sampling started on 20 April at 11:00 LT, when the volcanic plume was already over CMN (left part of the plot in Fig. 1b); therefore, the above sulphate concentration could not represent the peak value.

During this episode, about $90 \%$ of the $\mathrm{PM}_{10}$ sulphate was found in the fine $(<1 \mu \mathrm{m})$ fraction, with nitrates, ammonium and organic carbon (Fig. 1b) peaking in correspondence to the sulphate maximum, a feature typical of pollution aerosol. Similar behaviour was observed during the episode of 26 April: a strong increase in the accumulation mode particle number (Fig. 1a), not paired with a simultaneous increase in coarse particles, and characterised by high concentrations of $\mathrm{NO}_{3}^{-}$and WSOC, revealed the anthropogenic origin of 

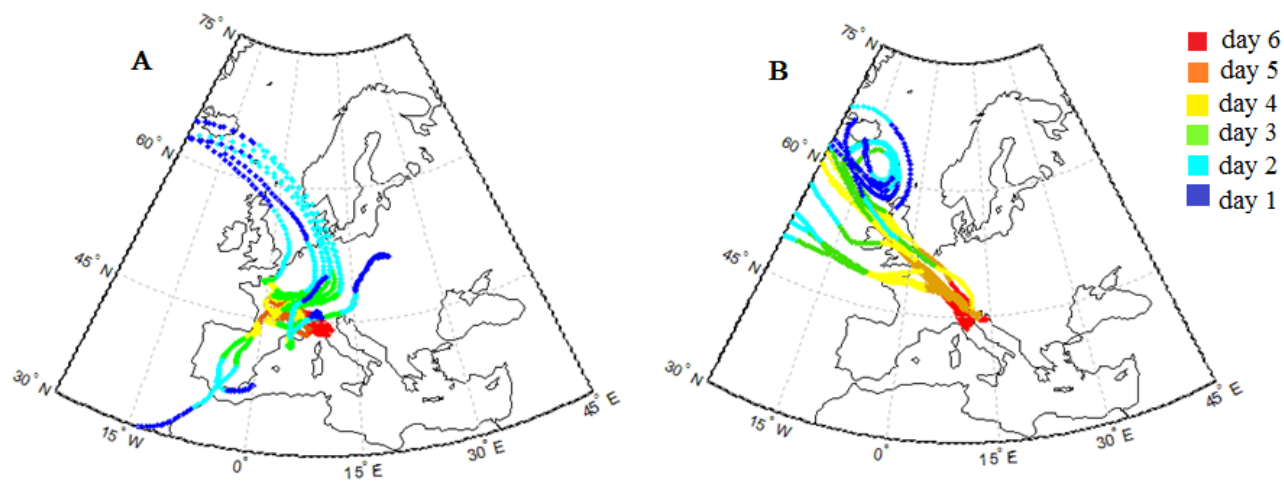

Fig. 2. Member of the back-trajectory ensembles travelling over the "Iceland" box for the two major events: 19-21 April (A) and 1820 May 2010 (B). The different colours identify the day of transport, starting from the source on day 1 and ending at CMN on day 6.

Table 1. Peak values and average and standard deviation for particle number concentrations (accumulation mode, coarse mode and total number), scattering and absorption coefficient, concentration of major inorganic ions and water soluble organic carbon (WSOC) at CMN during the two volcanic events and as average calculated during April and May over a $5 \mathrm{yr}$ reference period. Accumulation and coarse particle number concentrations are averaged on a $30 \mathrm{~min}$ basis, particle total number concentration and scattering/absorption coefficients on a 60 min time basis.

\begin{tabular}{|c|c|c|c|}
\hline & $\begin{array}{r}\text { Event I } \\
19-21 \text { Apr } 2010\end{array}$ & $\begin{array}{r}\text { Event II } \\
18-20 \text { May } 2010\end{array}$ & $\begin{array}{l}\text { April-May } \\
2006-2011\end{array}$ \\
\hline $\begin{array}{l}\text { Accumulation mode particles } \\
\left(\mathrm{cm}^{-3}\right)\end{array}$ & $\begin{array}{l}60.8 \pm 4.4 \\
\max : 122.8\end{array}$ & $\begin{array}{l}41.1 \pm 7.2 \\
\max : 245.0\end{array}$ & $\begin{array}{r}21.8 \pm 28.5 \\
\max : 245.0\end{array}$ \\
\hline $\begin{array}{l}\text { Coarse particles } \\
\left(\mathrm{cm}^{-3}\right)\end{array}$ & $\begin{array}{r}0.57 \pm 0.04 \\
\max : 1.3\end{array}$ & $\begin{array}{r}1.04 \pm 0.18 \\
\max : 4.3\end{array}$ & $\begin{array}{r}0.20 \pm 0.43 \\
\max : 4.9\end{array}$ \\
\hline $\begin{array}{l}\text { Total particle number } \\
\left(\mathrm{cm}^{-3}\right)\end{array}$ & $\begin{array}{r}2026 \pm 173 \\
\max : 4544\end{array}$ & $\begin{array}{r}4102 \pm 562 \\
\max : 6831\end{array}$ & $\begin{array}{r}2486 \pm 165 \\
\max : 10469^{a}\end{array}$ \\
\hline $\begin{array}{l}\text { Scattering coefficient } \\
\left(\mathrm{Mm}^{-1}\right)\end{array}$ & $\begin{array}{r}47.5 \pm 4.1 \\
\max : 84.9\end{array}$ & $\begin{array}{l}39.9 \pm 6.4 \\
\max : 134.5\end{array}$ & $\begin{array}{r}22.2 \pm 20.5 \\
\max : 163.0\end{array}$ \\
\hline $\begin{array}{l}\text { Absorption coefficient } \\
\left(\mathrm{Mm}^{-1}\right)\end{array}$ & $\begin{array}{r}3.37 \pm 0.28 \\
\max : 5.99\end{array}$ & $\begin{array}{r}2.39 \pm 0.28 \\
\max : 5.54\end{array}$ & $\begin{array}{r}1.60 \pm 1.78 \\
\max : 18.74\end{array}$ \\
\hline $\begin{array}{l}\mathrm{SO}_{4}, \mathrm{PM}_{1} / \mathrm{PM}_{1-10} \\
\left(\mu \mathrm{g} \mathrm{m}^{-3}\right)\end{array}$ & $2.14 / 0.22$ & $3.35 / 1.69$ & $0.41 \pm 0.90 / 0.10 \pm 0.13^{\mathrm{b}}$ \\
\hline $\begin{array}{l}\mathrm{NO}_{3}, \mathrm{PM}_{1} / \mathrm{PM}_{1-10} \\
\left(\mu \mathrm{g} \mathrm{m}^{-3}\right)\end{array}$ & $0.93 / 0.31$ & $0.43 / 0.16$ & $0.24 \pm 0.47 / 0.17 \pm 0.38^{b}$ \\
\hline $\begin{array}{l}\mathrm{NH}_{4}, \mathrm{PM}_{1} / \mathrm{PM}_{1-10} \\
\left(\mu \mathrm{g} \mathrm{m}^{-3}\right)\end{array}$ & $0.49 /<\mathrm{DL}$ & $1.10 / 0.01$ & $0.15 \pm 0.37 / 0.005 \pm 0.008^{b}$ \\
\hline
\end{tabular}

${ }^{a}$ The reference period for the particle total number concentration encompasses the years 2008-2010. ${ }^{\mathrm{b}}$ The reference period for sulphate, nitrate and ammonium encompasses years 2009-2011.

pollutants from the Po Valley, Italy. Here, in fact, a period of high pressure favoured the stagnation of air, with a consequent deterioration in air quality. All these features suggest that the aerosol collected on 20 April at CMN was probably a mixture of volcanic aerosol and aged PBL air, of local origin or picked up during the stagnation over central Europe before reaching the CMN site.

\subsection{Case 2: 18-20 May 2010}

According to the HYSPLIT analysis, air masses originating from the Icelandic region were present at $\mathrm{CMN}$ on 18
20 May 2010, when northerly winds continuously affected the measurement site (Fig. 4). In particular, starting from 18 May at 14:00 LT, high values of particle concentrations (peak values of coarse and accumulation mode particles: 4.2 and $144.7 \mathrm{~cm}^{-3}$, respectively) and scattering/absorption coefficients (peak values $105.6 \mathrm{Mm}^{-1}$ and $5.5 \mathrm{Mm}^{-1}$, respectively) were observed at CMN. A sudden decrease in particle concentration and scattering/absorption coefficient occurred on 19 May at 09:45 LT, when the measurement site was temporarily in cloud. It is conceivable that aerosol scavenging and cloud processing occurred in these conditions, which might explain the low concentrations of aerosol chemical 

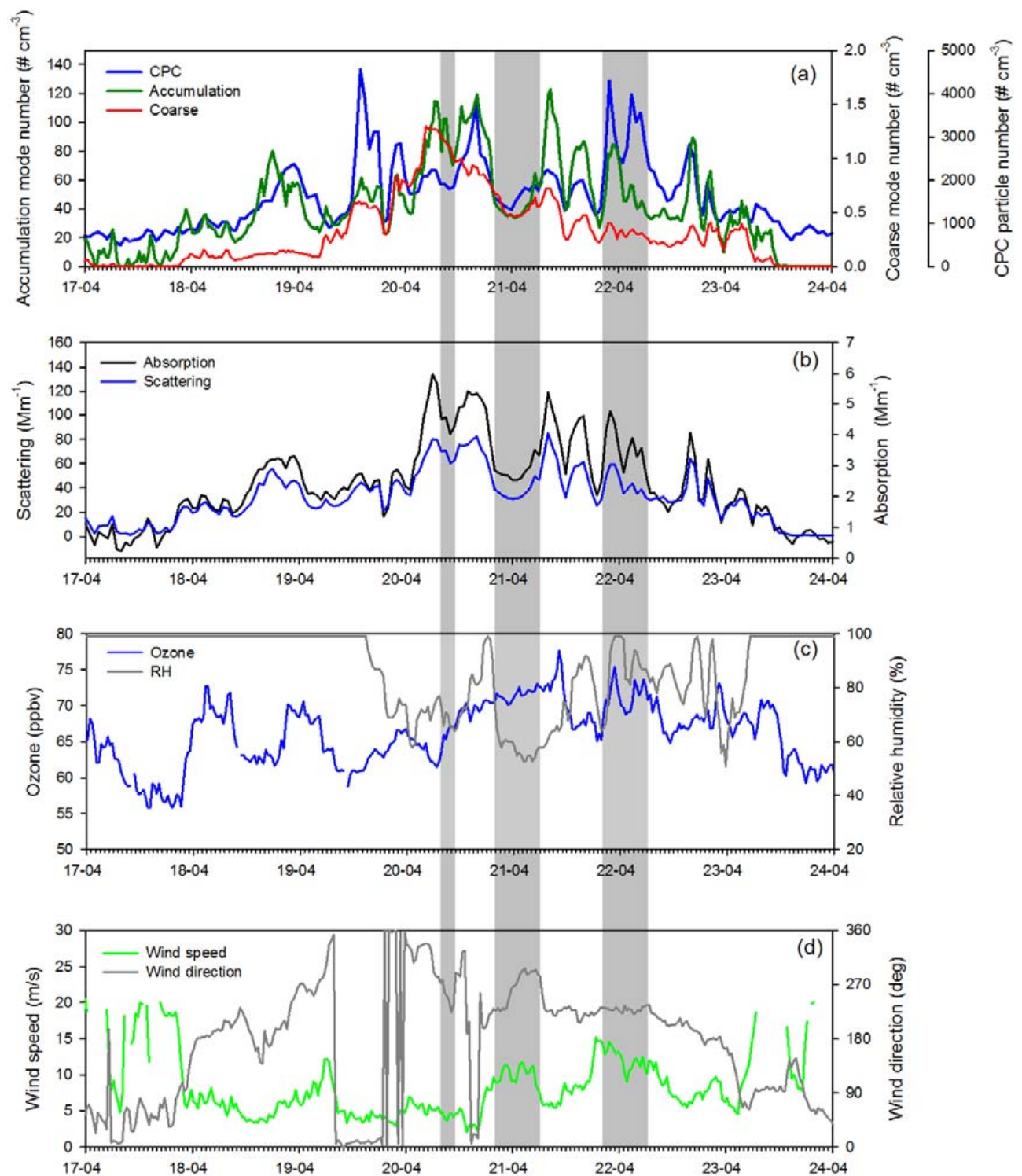

Fig. 3. April 2010: time series of (a) particle concentration $\left(\mathrm{cm}^{-3}\right)$ in the CPC, accumulation and coarse mode; (b) absorption and scattering coefficient; (c) surface ozone and relative humidity; and (d) wind speed and wind direction. The time periods covered by samples for chemical analyses are colour-coded.

constituents in the second sample collected during the May episode (Fig. 1b, grey bar).

A high coarse particle concentration $\left(>1.0 \mathrm{~cm}^{-3}\right)$ was again observed from 19 May at 18:00 LT until 20 May at 13:00 LT. During this period, an increase in fine particles (up to $6700 \mathrm{~cm}^{-3}$ ) was also observed, indicating the presence of an air mass characterised by high aerosol loading. Absorption and scattering coefficients peaked at $4.1 \mathrm{Mm}^{-1}$ and $134.5 \mathrm{Mm}^{-1}$, respectively. The accumulation mode particles exhibited two abrupt concentration increases (up to $240 \mathrm{~cm}^{-3}$ ) on 20 May (at 03:15 LT) and 21 May (at 04:15 LT), in conditions of very high RH (100\%).
The coarse mode was more pronounced compared to the April event with a peak concentration of $4.5 \mathrm{~cm}^{-3}$, corresponding to an increase of 900 times compared to the background concentration recorded on 17 April. The accumulation mode particles reached $150 \mathrm{~cm}^{-3}$, i.e. 30 times the concentration before the arrival of the volcanic plume (Fig. 4). The total number of fine particles was $6708 \mathrm{~cm}^{-3}$ (19 May at 20:00 LT), 10 times higher than background conditions.

As suggested by the HYSPLIT analysis (Fig. 2), the atmospheric transport was more straightforward in this case than for the April episode, though it was characterised by a similar transport time $(114 \pm 14 \mathrm{~h})$. The back-trajectory ensemble calculated for CMN spanned a large range of altitudes with 

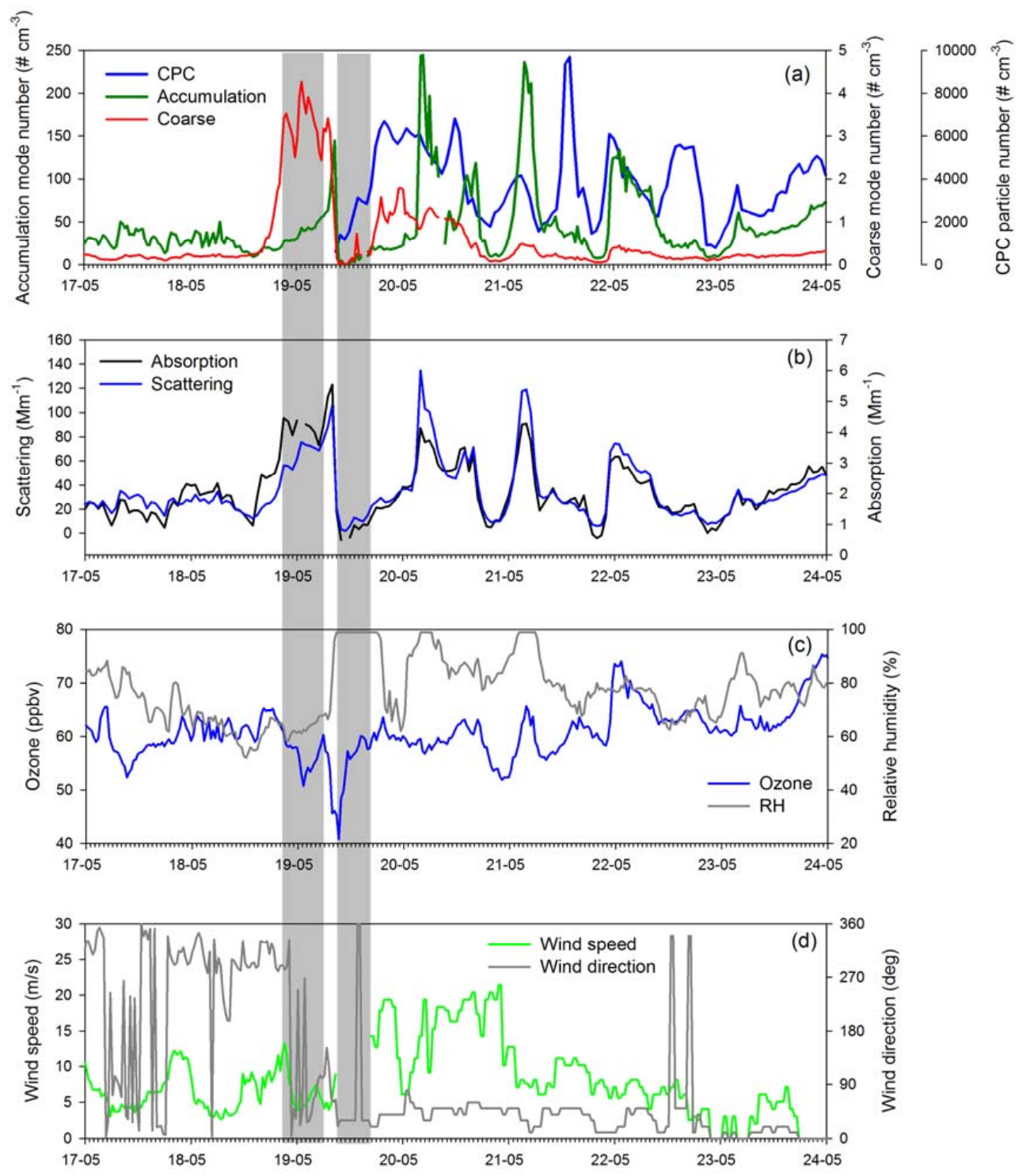

Fig. 4. May 2010: time series of (a) particle concentration $\left(\mathrm{cm}^{-3}\right)$ in the CPC, accumulation and coarse mode; (b) absorption and scattering coefficient; (c) surface ozone and relative humidity; and (d) wind speed and wind direction. The time periods covered by samples for chemical analyses are colour-coded.

air parcel pressure levels ranging from 900 to $400 \mathrm{hPa}$ over the Iceland region, suggesting that the volcanic plume could have been intercepted by air masses even at a lower altitude, i.e. in proximity to the emission.

In contrast to the April event, research flights over the Irish Sea on 16 May, the Norwegian Sea on 19 May (RautheSchöch et al., 2011), and over Switzerland and the Alps on 19 May (Bukowiecki et al., 2011) found the volcanic plume to be present in the free troposphere as a distinct layer, which was only subsequently transported into the boundary layer south of the Alps. The aerosol volume distribution (Fig. 5) again showed the build-up of a coarse mode centred at $2.5 \mu \mathrm{m}, 4$ times higher than on 20 April, and an accumu- lation mode peaking at $234 \mathrm{~nm}$, i.e. with a smaller size with respect to the previous episode ( $304 \mathrm{~nm}$ in May) but of comparable intensity.

In this occurrence, fine aerosol $\mathrm{SO}_{4}^{2-}$ reached a maximum of $3.5 \mu \mathrm{g} \mathrm{m}^{-3}$. This concentration corresponds to the 92th percentile of the spring data for the years 2009-2011, and is more than eight times higher than the spring average $\left(0.41 \pm 0.90 \mu \mathrm{g} \mathrm{m}^{-3}\right)$ for the whole $3 \mathrm{yr}$ data set. Concentrations as high as $3.5 \mu \mathrm{g} \mathrm{m}^{-3}$, though infrequent, sometimes occur at $\mathrm{CMN}$, especially during summer, when convection carries polluted air masses from the Po Valley to the station. What is unusual in this case, and provides the ash plume signature, is the absence of a simultaneous increase in organic 


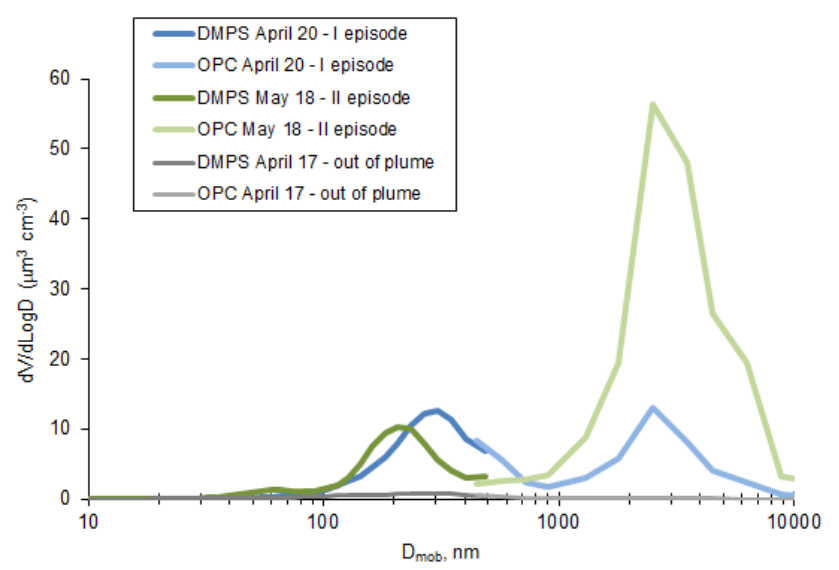

Fig. 5. Comparison between the aerosol size distribution before the arrival of the volcanic plume, 17 April (black/grey - out of plume), and during its most intense impact on 20 April (blue/light blue - I episode) and 18 May (green/light green - II episode), derived from DMPS (10-500 nm) and OPC (300 nm-20 $\mu \mathrm{m})$ measurements.

or nitrate aerosol mass, as shown by the minimum of the $\mathrm{NO}_{3}^{-} / \mathrm{SO}_{4}^{2-}$ ratio for the period (Fig. 1b). This ratio can be useful for distinguishing natural sources of sulphates, such as volcanic plumes or Saharan dust transports, from anthropogenic sources where nitrates are generally simultaneously present. Volcanic plumes are normally characterised by high concentrations of sulphates not associated with either nitrate or organic compounds.

On 18 May an $\mathrm{NH}_{4}^{+}$concentration of $1.10 \mu \mathrm{g} \mathrm{m}^{-3}$ was also measured. This concentration, corresponding to the 97 th percentile for the years 2009-2011, was significantly higher than the spring average $\left(0.15 \pm 0.37 \mu \mathrm{g} \mathrm{m}^{-3}\right)$ of the whole $3 \mathrm{yr}$ data set and indicates an enrichment in ammonium against background conditions, which are normally very low at $\mathrm{CMN}$ due to the absence of significant sources (Carbone et al., 2010). This ammonium could have resulted from the volcanic emission of $\mathrm{NH}_{3}$ (Rose et al., 1986; Allen et al., 2000) or, more probably (given the long distance travelled by the air mass), from the neutralisation of acidic sulphate particles during the transport downwind.

In contrast to the April volcanic plume, on 18 May $66 \%$ of the total water soluble sulphate was found in the fine fraction and the remaining $34 \%$ in the coarse one (Fig. 1b), probably resulting from the condensation of $\mathrm{H}_{2} \mathrm{SO}_{4}$ on the surface of mineral particles, as confirmed by SEM observations performed by other authors (Lettino et al., 2012; O'Dowd et al., 2012). Lettino et al. (2012) undertook SEM analyses of particles collected during the volcanic plume in Rimini, Italy $(150 \mathrm{~km}$ East of CMN). They observed in the coarse fraction the presence not only of mineral Ca-sulphates (gypsum) but also secondary particles morphologically similar to those constituting the fine fraction, i.e. complex secondary particles coagulated onto existing particles, mainly composed of ammonium nitrate and sulphate and sodium sulphate. Schu- mann et al. (2011) found the same fine secondary particles adhering to the surfaces of many coarse particles. In the presence of a large number of pre-existing ash particles, in fact, the energetically favoured path for gases is to condense onto particle surfaces, rather than forming new ones through the nucleation of sulphuric acid droplets, as suggested by Schumann et al. (2011) and shown by Boulon et al. (2011). We argue that, in this process, the large number of coarse particles observed on 18 May, 3 times higher than in April (Fig. 4), competed with fine particles in the adsorption/condensation of sulphuric acid and other volatile species. In both episodes, chemical analysis showed a fine fraction of aerosol dominated by sulphate and a coarse mode dominated by crustal elements, mainly $\mathrm{Na}, \mathrm{K}, \mathrm{Al}, \mathrm{Ca}, \mathrm{Fe}$ (here listed in order of decreasing concentration). This explains the bimodality of the volume distribution (Fig. 5), where the high concentration of coarse particles resulted from primary volcanic ash, while the accumulation mode was composed of liquid sulphuric acid or sulphate droplets, only partly neutralised by ammonia.

All physical and chemical data point to a substantial difference between the two volcanic plumes detected at CMN, which could be in part ascribed to changing eruption characteristics, but more likely was mostly the result of different transport processes. The volcanic plume during the April event was more diluted and superimposed over regional anthropogenic pollution, probably due to PBL interaction before reaching CMN: the PBL over the Po Basin was, in fact, well mixed on 20 April with a boundary layer height of about $1600 \mathrm{~m}$ (Belosi et al., 2011). In this case, aerosol at $\mathrm{CMN}$ also exhibited chemical features characteristic of anthropogenic PBL aerosol, i.e. high nitrates and organics, appearing as a mixture of volcanic and non-volcanic air (Fig. 1b). Moreover, from ICP-MS analyses, elements typically attributed to anthropogenic emissions, such as $\mathrm{Cd}, \mathrm{Sb}$, $\mathrm{Mo}, \mathrm{Pb}$ and $\mathrm{Cr}$, appeared in higher concentrations compared to the subsequent days. Such elements were mainly present in the fine and soluble fraction of PM, as is typical of anthropogenic emissions (Canepari et al., 2010).

Further confirmation of the differences is the shift of the accumulation mode toward larger diameters in April (about $304 \mathrm{~nm}$ ) compared to the May episode $(234 \mathrm{~nm}$ ) (Fig. 5), as similarly observed at Jungfraujoch, Switzerland (Bukowiecki et al., 2011). Sulphate aerosol size, characterising most of the accumulation mode, strongly depends on local meteorological conditions, particularly on relative humidity, which determines the hygroscopic growth of particles. For "non in-cloud" samplings in April and May, RH values at CMN were quite similar (Figs. 3 and 4). Therefore, the shift in diameter is likely to reflect the longer ageing of the April plume over central Europe before being transported to CMN. Conversely, the coarse fraction diameter was centred at $2.5 \mu \mathrm{m}$ in both cases, indicating distance from the source to be the main factor controlling the size distribution of this class of particles. 
Because of the incomplete coverage by off-line chemical analyses of the April episode (sampling began when the plume was already over $\mathrm{CMN}$ ), and because the May episode was much more impacted by ash particles than the previous one, the latter episode was felt to merit special attention. Thus, the following analysis based on trace element measurements refers to it alone.

\subsection{Ash composition}

Elemental analyses by PIXE-PIGE were performed only during the volcanic plume observation period, from 20 April to 19 May 2010, so no information exists on annual or monthly averages of such elements at CMN. The only data for elemental concentrations at this site are found in Marenco et al. (2006), where the aerosol chemical composition during summer 2004 was investigated by ED-XRF.

The present PIXE-PIGE data show that, on 18 May, most of the typically crustal elements displayed high concentrations in the coarse fraction, reflecting their insoluble form as mineral crystals or glass shards. Major elements present in the coarse fraction of aerosol at CMN on 18 May were $\mathrm{Na}\left(1.05 \mu \mathrm{g} \mathrm{m}^{-3}\right), \mathrm{K}\left(1.02 \mu \mathrm{g} \mathrm{m}^{-3}\right), \mathrm{Al}\left(0.9 \mu \mathrm{g} \mathrm{m}^{-3}\right)$, $\mathrm{Ca}\left(0.65 \mu \mathrm{g} \mathrm{m}^{-3}\right), \mathrm{Fe}\left(0.57 \mu \mathrm{g} \mathrm{m}^{-3}\right), \mathrm{Mg}\left(0.26 \mu \mathrm{g} \mathrm{m}^{-3}\right)$, and $\mathrm{Ti}\left(0.073 \mu \mathrm{g} \mathrm{m}^{-3}\right)$, which match well with those defined by the Institute of Earth Sciences (http://earthice.hi.is/ eyjafjallajokull_2010_chemical_composition) for the main oxides in the volcanic ash from Iceland.

In general, all the crustal elements had much higher concentrations during the volcanic plume transit than on other days in the same period, representing an important indication of the volcanic influence. However, this attribution is uncertain in the context of long-range transport of ubiquitous trace species (Colette et al., 2011). In fact, although some elements are enriched in the ash compared to Earth's crust composition, they also have rather high background values due to anthropogenic emissions or other sources. In the study performed at CMN by Marenco et al. (2006), several elements among those enriched on $18 \mathrm{May}(\mathrm{Mg}, \mathrm{Al}, \mathrm{Si}$, $\mathrm{K}, \mathrm{Ca}, \mathrm{Ti}, \mathrm{Mn}, \mathrm{Fe}$ and $\mathrm{Sr}$ ) were associated with mineral dust transported from the northern Sahara and were found in the supermicronic fraction of aerosol. Saharan dust events are the main phenomena that usually contribute to the concentration of coarse particles at CMN, with maximum occurrence in spring/summer. Back trajectories (Figs. 1-2) had already ruled out a possible Saharan contribution to the high concentrations of crustal particles on 18 May, confirming the air mass passage over Iceland before reaching CMN. As further confirmation of the volcanic origin of these crustal particles, the total $\mathrm{PM}_{10}$ aerosol composition obtained from PIXE-PIGE measurements was compared to that of volcanic ash collected on 16 May (GSV165-3) at the eruption site (Fig. 6) (Sigmundsson et al., 2010; http://earthice.hi.is/ eyjafjallajokull_2010_chemical_composition). The comparison was performed using elemental ratios, which are more

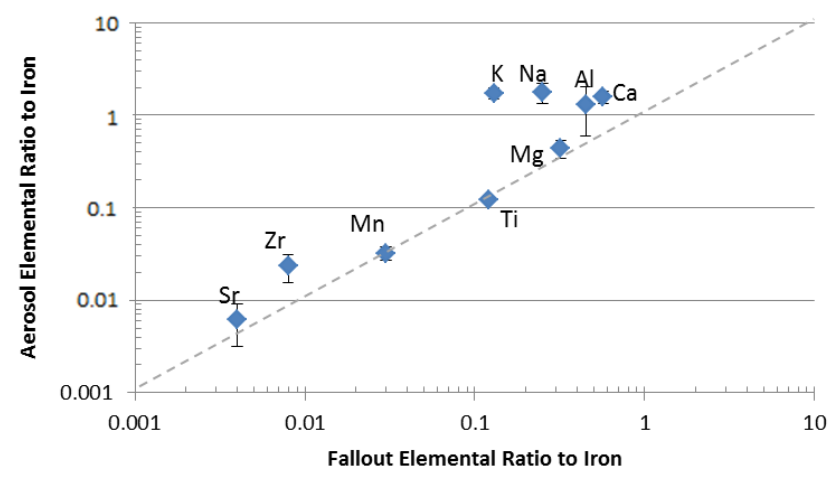

Fig. 6. Elemental ratio to iron in the aerosol sample collected at CMN on 18 May 2010 vs. direct fallout collected on 16 May (GSV165-3) near the Eyjafjallajökull crater (http://earthice.hi.is/ eyjafjallajokull_2010_chemical_composition). The dashed line indicates equal ratio. Data refer to PIXE-PIGE analyses.

robust than single element concentrations in univocally identifying sources.

A good agreement exists with the fallout sample for some elements ( $\mathrm{Ti}, \mathrm{Mn}, \mathrm{Mg}, \mathrm{Sr}$ ), while other elements displayed bigger discrepancies. The reason for the larger deviations could be found or in the presence of different sources for some elements at CMN (e.g. a marine contribution cannot be excluded for $\mathrm{Na}$ ) or in the processes of interaction between gas-phase material and ash within the volcanic vent, as suggested by some authors. According to Witham et al. (2005), in fact, the co-emission of ash and gases in the atmosphere during volcanic eruptions starts a number of physical and chemical processes not yet fully understood, the ultimate fate of which is the adsorption of magmatic volatiles as watersoluble minerals on ash surfaces within the eruptive column. Since in this process finer particles experience enhanced adsorption, as a result of their larger surface to mass ratio, elements which are abundant in volcanic gases are enriched onto the finest fraction of aerosol, whose proportion increases with the distance from the source due to the longer gravitational settling compared to coarse particles. This could explain the different behaviour in Fig. 6 of litophile elements, such as $\mathrm{Mg}, \mathrm{Mn}, \mathrm{Sr}$, Ti and $\mathrm{Ca}$, which form poorly volatile ionic compounds (Symonds et al., 1987) and are therefore emitted essentially via volcanic ash (Bagnato et al., 2013), compared to elements which instead are abundant also in the gas phase ( $\mathrm{Na}$ and $\mathrm{Ca}$, but also, to a lesser extent, $\mathrm{K}$ and $\mathrm{Zr}$ ) from magma degassing, which are adsorbed on the surface of fine ashes.

ICP-MS analyses of the aerosol samples supplied further corroboration of the volcanic influence on the aerosol at CMN during the two episodes. They showed the enrichment of trace elements such as the chalcophile metal $\mathrm{Tl}$, whose presence in volcanic plumes is due to the degassing of silicate melts (Hinkley et al.,1994), and the more refractory rare 

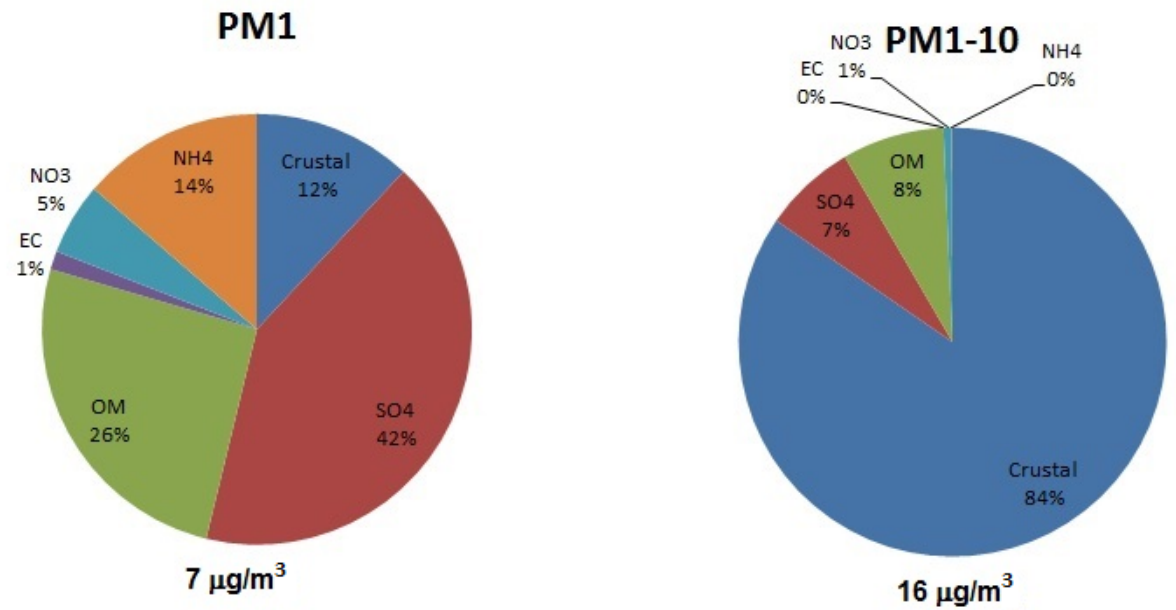

Fig. 7. Reconstructed mass for the 18 May episode, separated into the fine (left) and coarse (right) fractions. The reconstructed mass is indicated below the figure. The total $\mathrm{PM}_{10}$ reconstructed mass was $23 \mu \mathrm{g} \mathrm{m}^{-3}$.

earth elements $\mathrm{La}$ and $\mathrm{Ce}$, known to be enriched in volcanic plumes (Moune et al., 2006).

\subsection{PM $_{10}$ mass budget}

The chemical analyses of the $\mathrm{PM}_{1}$ and $\mathrm{PM}_{1-10}$ samples collected on 18 May were used to reconstruct the collected $\mathrm{PM}_{10}$ mass. It was assumed that the crustal elements from PIXE-PIGE measurements were present in their main oxide forms at the highest oxidation state.

Silicon, not determined due to the use of quartz sampling filters, was estimated from the Ti concentration, taking the $\mathrm{Si} / \mathrm{Ti}$ ratio of the volcanic ash composition and transforming to $\mathrm{SiO}_{2}$ mass. Sulphate, nitrate and ammonium concentrations were measured by ionic chromatography, while organic matter was estimated by multiplying the concentration of organic carbon by 1.8. This organic mass-organic carbon (OM/OC) ratio was derived from AMS data collected during the PEGASOS (Pan-European Gas-AeroSOls-climate interaction Study) experimental campaign in summer 2012 at CMN. It is a value representative of oxygenated and/or functionalised organic species typical of processed aerosol (Gelencsér, 2004; Aiken et al., 2008), which takes into account the occurrence of biogenic aerosol and, in some cases, the presence of more oxygenated anthropogenic aged particles.

It is evident from the mass reconstruction (Fig. 7) that the fine fraction was dominated by ammonium sulphate $(56 \%)$. OC was also significant $-2.0 \mu \mathrm{g} \mathrm{m}^{-3}$ organic matter $(26 \%)$ while minor constituents were nitrate, EC and crustal oxides $\left(0.84 \mu \mathrm{g} \mathrm{m}^{-3}\right)$. On average, during the whole observation period (20 April-19 May), the two main contributors, ammonium sulphate and organic matter, were found in a nearly 1:1 proportion, as also observed by Marenco et al. (2006) at the same site. However, the strong increase in fine sulphate in the presence of the volcanic plume made this component dominant on 18 May. By contrast, on the same day, $\mathrm{PM}_{1-10}$ were dominated by a mineral component represented by volcanic ash, amounting to $84 \%$ of the total mass, with sulphates and organic matter as minor components.

The total reconstructed $\mathrm{PM}_{10}$ mass of aerosol during the 18 May volcanic transport amounted to $23 \mu \mathrm{g} \mathrm{m}^{-3}$, of which $7 \mu \mathrm{g} \mathrm{m}^{-3}$ as $\mathrm{PM}_{1}$ and $16 \mu \mathrm{g} \mathrm{m}^{-3}$ as $\mathrm{PM}_{1-10}$, with a $\mathrm{PM}_{1} / \mathrm{PM}_{10}$ ratio of 0.3 . The same ratio measured gravimetrically at CMN during summer with $24 \mathrm{~h}$ samplings (Marenco et al., 2006) was 0.47 . The significantly lower value during the volcanic transport is mostly attributable to the large increase in the coarse particles number occurring on 18 May, which had resulted from the presence of the volcanic ash and accounted for most of the aerosol mass.

\subsection{Mass contribution of volcanic ash to total $\mathrm{PM}_{10}$ at CMN}

In order to estimate the volcanic ash contribution on the total $\mathrm{PM}_{10}$ at $\mathrm{CMN}$, the elemental composition of the filter samples was used, in particular the concentrations of some elements, namely Al, $\mathrm{Fe}, \mathrm{Ti}$ and $\mathrm{Mn}$, measured by PIXE-PIGE. The same method was applied at sampling sites in other parts of Europe (Colette et al., 2011; Bukowiecki et al., 2011), in some cases using different tracers, such as $\mathrm{Sr}, \mathrm{Y}$ and $\mathrm{Zr}$ (Krabbe et al., 2010; Schäfer et al., 2011).

$\mathrm{Al}, \mathrm{Fe}, \mathrm{Ti}$ and $\mathrm{Mn}$ were selected because they displayed a strong mutual correlation (correlation coefficients all >0.9), confirming their common origin. They showed a simultaneous increase and subsequent decrease during the episodes of 20 April and 18 May, which probably indicates they share the same origin. Moreover, these species are known to be important contributors to volcanic ash chemical composition, with abundances of $8.3 \%(\mathrm{Al}), 7.5 \%(\mathrm{Fe}), 1.0 \%(\mathrm{Ti})$ 
and $0.2 \%(\mathrm{Mn})$ (http://earthice.hi.is/eyjafjallajokull_2010_ chemical_composition). Finally, their enrichment factor (ratio of their average concentration in the volcanic ash and the Earth's crust) is $>2$ (Schäfer et al., 2011). Ti, in particular, can be considered a source-specific tracer for volcanic aerosol, or more in general, for crustal materials, since its concentrations at CMN are low (Marenco et al., 2006), as opposed to $\mathrm{Fe}, \mathrm{Al}$ and $\mathrm{Mn}$, which, in some cases, can be influenced by anthropogenic sources. In fact, during the observation period, Ti concentrations measured by PIXE were above detection limits only in the samples corresponding to the two volcanic plume transits, with a maximum of $73 \mathrm{ng} \mathrm{m}^{-3}$ on 18 May. This concentration was more than 2 times higher than the mean of $30 \mathrm{ng} \mathrm{m}^{-3}$ reported in Marenco et al. (2006) as measured by ED-XRF during a summer campaign at CMN (90th percentile equal to $58 \mathrm{ng} \mathrm{m}^{-3}$ ). Even so, according to the authors, that concentration cannot be assumed representative of the annual average at $\mathrm{CMN}$, as their measurements refer to a relatively short period of time and to the summer season only; moreover the summer campaign was under the influence of Saharan dust transports, which are known to contribute to the concentration of mineral elements, including Ti; hence, the $30 \mathrm{ng} \mathrm{m}^{-3}$ average does not represent a real background concentration but a somehow higher concentration.

For all such elements, background concentrations measured on 11 May (a day not affected by volcanic particles) were subtracted from those recorded during the volcanic plume transits. In this way, the amount of volcanic aerosol present at CMN was estimated, taking into account the relative abundances of the four elements in the ash collected near the volcano. The mass content of $\mathrm{TiO}_{2}$ in the volcanic aerosol was $0.3 \%$ on 18 May, which was slightly lower than that observed at the Swiss free tropospheric station JFJ by Bukowiecki et al. (2011) during the same episode (0.5\%).

The impact of the volcanic ashes on $\mathrm{PM}_{10}$ at $\mathrm{CMN}$ was estimated to be in the range from 7.3 to $9.5 \mu \mathrm{g} \mathrm{m}^{-3}$ (average $9 \pm 1 \mu \mathrm{g} \mathrm{m}^{-3}$ ), i.e. between $32 \%$ and $41 \%$ (average $39 \pm 4 \%$ ) of the total reconstructed mass of $\mathrm{PM}_{10}$ $\left(23 \mu \mathrm{g} \mathrm{m}^{-3}\right)$. This indicates that the volcanic ash contribution was superimposed on a background $\mathrm{PM}_{10}$ mass of about $14 \mu \mathrm{g} \mathrm{m}^{-3}$, a value very close to the average $\mathrm{PM}_{10}$ mass of $16 \mu \mathrm{g} \mathrm{m}^{-3}$ measured by Marenco et al. (2006) at the same site during a 3-month summer campaign in 2004. In May, on the basis of $\mathrm{CO}, \mathrm{O}_{3}$ and $\mathrm{BC}$ measurements at $\mathrm{CMN}$ (Marinoni et al., 2008; Cristofanelli et al., 2013), it can be assumed that the local meteorology already presents features typical of the warm period, when the site is affected by emission sources located in northern Italy and continental Europe, transported by valley breezes or convective activity from the boundary layer, even during the night (Marinoni et al., 2008). The volcanic plume almost doubled the background aerosol concentration at CMN, though this contribution was smaller than that observed in other parts of Europe. A summary of the volcanic contributions calculated from chemical tracers or esti- mated by models is reported in Table 2 for the two episodes separately. The table exhibits high variability in such estimates arising from variability in the input parameters (composition of volcanic ash and $\mathrm{PM}_{10}$ sample analysis).

Compared to the April episode, the estimates of the volcanic contribution in May denote an overall better coherence, with decreasing intensity at increasing distance from the source, despite the small number of observations. On this occasion volcanic contributions of up to $70 \%$ were observed in Switzerland (Bukowiecki et al., 2011). A $60 \%$ volcanic contribution is reported at a high altitude station in France (Puy de Dome, $1465 \mathrm{~m}$ a.s.1.). According to the authors (Hervo et al., 2012), the $33 \%$ Flexpart estimate at Puy de Dome, reported in Table 2 for the same site, would represent an underestimate, partly explained by the fact that the model does not simulate the formation of secondary aerosols. By contrast, the April episode denotes a higher degree of variability in the volcanic contributions calculated at different sites. This probably reflects the various degrees of mixing between volcanic plume and PBL air during the episode, again suggestive of the different transport dynamics of the two described events, with concurrent contributions of other than the volcanic source in April at different sites, which are difficult to quantify.

During the April event a $19 \%$ volcanic contribution was estimated at CMN. At an even longer distance, in Puglia, southern Italy, Perrone et al. (2012) reported a maximum volcanic ash contribution of $19 \%$ to total $\mathrm{PM}_{10}$, derived from Flexpart simulations. To our knowledge no similar estimates exist for other sites south of the Alps, although observations of the plume were reported over Spain and Greece.

\section{7 $\mathbf{P M}_{10}$ mass concentration in the Po Valley}

$\mathrm{PM}_{10}$ concentrations recorded by the Air Pollution Monitoring Network of the Regional Agency for Environmental Protection in the urban area of Bologna (Italy) and in the lowland site of San Pietro Capofiume (SPC) (40 km north-east of Bologna in the Po Valley) were analysed to evaluate whether the volcanic plume had an impact on air quality also within the densely populated Po Valley. Data (daily averages) did not evidence any marked increase in $\mathrm{PM}_{10}$ concentrations for the April episode, while a significant increase was observed on 18 May, almost exclusively for particle sizes larger than $2.5 \mu \mathrm{m}$ (Fig. 8). Indeed, the weak signal recorded by these low altitude stations during the April episode was probably attributable to the strong dilution of the volcanic plume combined with the masking effect of anthropogenic pollution. In fact, both sites are characterised by much higher mass concentrations of particles, compared to the background site of $\mathrm{CMN}$; hence, a relatively small volcanic contribution superimposed on a much higher background would be hard to distinguish.

During the May episode, ground-level $\mathrm{PM}_{10}$ data displayed a relative maximum on 19 May which, compared to 
Table 2. Summary of volcanic contributions to total $\mathrm{PM}_{10}$ observed at different sites in Europe and estimated by the indicated method.

\begin{tabular}{|c|c|c|c|c|c|c|}
\hline Author & Site & $\begin{array}{l}\text { Alt. } \\
(\mathrm{m})\end{array}$ & $\begin{array}{c}\mathrm{PM}_{10} \\
\left(\mu \mathrm{g} \mathrm{m}^{-3}\right)\end{array}$ & $\begin{array}{l}\text { Volcanic contrib. } \\
\qquad\left(\mu \mathrm{g} \mathrm{m}^{-\mathbf{3}}\right)\end{array}$ & $\begin{array}{r}\% \\
\text { on } \mathrm{PM}_{10}\end{array}$ & Method \\
\hline \multicolumn{7}{|l|}{ Episode 19-21 April } \\
\hline \multirow[t]{2}{*}{ Pitz et al. (2011) } & Augsburg, Germany & 484 & & 12 (av.) & 30 (av.) & Positive Matrix \\
\hline & $\left(48^{\circ} 22^{\prime} \mathrm{N}, 10^{\circ} 54^{\prime} \mathrm{E}\right)$ & & & $35(\max )$ & $65(\max )$ & Factorization \\
\hline \multirow[t]{2}{*}{ Schäfer et al. (2011) } & $\begin{array}{l}\text { Augsburg, Germany } \\
\left(48^{\circ} 22^{\prime} \mathrm{N}, 10^{\circ} 54^{\prime} \mathrm{E}\right)\end{array}$ & 484 & & $17 \pm 7$ & $25 \pm 10$ & $\begin{array}{l}\text { Chemical tracers } \\
(\mathrm{Ti}, \mathrm{Mn}, \mathrm{Sr}, \mathrm{Y}, \mathrm{Zr})\end{array}$ \\
\hline & $\begin{array}{l}\text { Andechs, Germany } \\
\left(47^{\circ} 58^{\prime} \mathrm{N}, 11^{\circ} 11^{\prime} \mathrm{E}\right)\end{array}$ & 690 & & $10 \pm 4$ & $26 \pm 10$ & Chemical tracers \\
\hline Colette et al. (2011) & $\begin{array}{l}\text { Mulhouse, France } \\
\left(47^{\circ} 45^{\prime} \mathrm{N}, 7^{\circ} 19^{\prime} \mathrm{E}\right)\end{array}$ & 240 & 56 & $30 \pm 10$ & $54 \pm 18$ & $\begin{array}{l}\text { Chemical tracers } \\
(\mathrm{Al}, \mathrm{Fe}, \mathrm{Ti})\end{array}$ \\
\hline Bukowiecki et al. (2011) & $\begin{array}{l}\text { Basel, Switzerland } \\
\left(47^{\circ} 34^{\prime} \mathrm{N}, 7^{\circ} 36^{\prime} \mathrm{E}\right)\end{array}$ & 260 & 51.5 & 45 & 87 & $\begin{array}{l}\text { Chemical tracers } \\
\text { (Ti) }\end{array}$ \\
\hline Perrone et al. (2012) & $\begin{array}{l}\text { Lecce, Italy } \\
\left(40^{\circ} 21^{\prime} \mathrm{N}, 18^{\circ} 10^{\prime} \mathrm{E}\right)\end{array}$ & 50 & 24 & 4.5 & 19 & $\begin{array}{l}\text { Flexpart } \\
\text { simulation }\end{array}$ \\
\hline This study & $\begin{array}{l}\text { Mt. Cimone, Italy } \\
\left(44^{\circ} 11^{\prime} \mathrm{N}, 10^{\circ} 42^{\prime} \mathrm{E}\right)\end{array}$ & 2165 & 18 & $3 \pm 2$ & $18 \pm 9$ & $\begin{array}{l}\text { Chemical tracers } \\
(\mathrm{Al}, \mathrm{Fe}, \mathrm{Ti}, \mathrm{Mn})\end{array}$ \\
\hline \multicolumn{7}{|l|}{ Episode 18-20 May } \\
\hline \multirow[t]{2}{*}{ Bukowiecki et al. (2011) } & $\begin{array}{l}\text { Lugano, Switzerland } \\
\left(46^{\circ} 00^{\prime} \mathrm{N}, 8^{\circ} 57^{\prime} \mathrm{E}\right)\end{array}$ & 280 & $26.1(24 \mathrm{~h})$ & 18.8 & 72 & $\begin{array}{l}\text { Chemical tracers } \\
\text { (Ti) }\end{array}$ \\
\hline & $\begin{array}{l}\text { Magadino, Switzerland } \\
\left(46^{\circ} 08^{\prime} \mathrm{N}, 8^{\circ} 51^{\prime} \mathrm{E}\right)\end{array}$ & 204 & $26.3(24 \mathrm{~h})$ & 18.3 & 70 & $\begin{array}{l}\text { Chemical tracers } \\
\text { (Ti) }\end{array}$ \\
\hline \multirow[t]{2}{*}{ Hervo et al. 2012} & $\begin{array}{l}\text { Puy de Dôme, France } \\
\left(45^{\circ} 46^{\prime} 0 \mathrm{~N}, 2^{\circ} 57^{\prime} \mathrm{E}\right)\end{array}$ & 1465 & $39 \pm 4$ (TSP) & $13 \pm 4$ & 30 & $\begin{array}{l}\text { Flexpart } \\
\text { simulation }\end{array}$ \\
\hline & & & $52 \pm 9$ & $30 \pm 4$ & 60 & $\begin{array}{l}\mathrm{PM}_{10} \text { difference from } \\
\text { background conc. }\end{array}$ \\
\hline This study & $\begin{array}{l}\text { Mt. Cimone, Italy } \\
\left(44^{\circ} 11^{\prime} \mathrm{N}, 10^{\circ} 42^{\prime} \mathrm{E}\right)\end{array}$ & 2165 & $\begin{array}{r}23 \\
\text { (reconstr.) }\end{array}$ & $9 \pm 1$ & $37 \pm 5$ & $\begin{array}{l}\text { Chemical tracers } \\
(\mathrm{Al}, \mathrm{Fe}, \mathrm{Ti}, \mathrm{Mn})\end{array}$ \\
\hline
\end{tabular}

the day before the arrival of the plume (17 May), denoted a $\mathrm{PM}_{10}$ increase in the coarse fraction corresponding to about $10 \mu \mathrm{g} \mathrm{m}^{-3}$ at Bologna and $7 \mu \mathrm{g} \mathrm{m}^{-3}$ at SPC. These amounts are similar to the $9 \mu \mathrm{g} \mathrm{m}^{-3}$ volcanic contribution estimated at CMN from Ti concentration. Considering that the volcanic layer portion entrained was subsequently mixed in the PBL volume, this would result in a dilution of the volcanic contribution at ground level. Unfortunately the actual dilution ratio cannot be easily determined. From lidar observations, in fact, we know that the lowest part of the volcanic layer was actually detected in the PBL on 18 May (Pappalardo et al., 2013), but the thickness of the entrained layer is unclear. Therefore we conclude that the increase in $\mathrm{PM}_{10}$ observed at ground level must be considered as an upper limit for the volcanic contribution, and that it probably cannot be entirely attributed to volcanic ash but could partly result from other local sources.

Conversely, the correspondence of the relative peak of 26 April with the accumulation mode peak observed at CMN (Fig. 1) leads us to attribute this peak to pollution transport from the PBL, in the presence of a persistent high pressure period. Measurements of optical and physical aerosol properties performed at SPC by a ground-based radiometer (Campanelli et al., 2012) confirm that, at least during the April episode, the transit of the volcanic plume was not unequivocally detectable due to the mixing with high particulate matter concentrations typical of the Po Valley.

\section{Conclusions}

This paper presents the results of continuous measurements of aerosol physical parameters and off-line chemical analyses of aerosol samples collected during April and May 2010. Such data allow the detection of the Icelandic Eyjafjallajökull volcanic plume transit to CMN in northern Italy, after a long-range transport of more than $3000 \mathrm{~km}$. During the eruption period, two main events impacted the site, the first on 19-21 April and the second between 18 and 20 May. The two events were both identified by a sudden increase in the fine mode particle number, accompanied by a proportionally higher build-up of the coarse particle number. The presence of volcanic emissions in the free troposphere at CMN was confirmed by back-trajectory analysis and by the off-line analysis of the chemical composition of the aerosol, which exhibited chemical features typical of volcanic ash, starting with an increase in sulphate concentration.

The presented data show that, in both the episodes described here, the volcanic plume reached CMN strongly diluted as a result of the long distance from the source. The simultaneous increase in the concentrations of elements such as $\mathrm{Fe}, \mathrm{Al}, \mathrm{Mn}, \mathrm{Ti}$ and $\mathrm{Cr}$ support the volcanic nature of the transported materials.

The ash (coarse fraction) was mainly composed of silicate glass and crystalline material, reflecting the chemical composition of the magma from which it derived and that of the 
conduit rocks eroded during the eruption, largely consisting of silica and aluminium oxides, with smaller proportions of other oxides, materials that do not easily solubilise in water. By contrast, the fine aerosol fraction detected during the two episodes appears to be mainly composed of acidic sulphates, likely produced by the oxidation of the $\mathrm{SO}_{2}$ degassed by the volcano and sulphuric acid subsequently condensed on preexisting or freshly nucleated particles.

The concentration of sulphate in $\mathrm{PM}_{1}$ during the most intense event of 18 May reached a relative maximum not correlated with other pollutants, such as nitrate or organic carbon, a feature typical of air parcels of volcanic origin. Calculations of $\mathrm{PM}_{10}$ based on specific volcanic tracers measured by PIXE-PIGE, i.e. Fe, Ti, $\mathrm{Al}, \mathrm{Mn}$, and the concentrations of the same elements in the ash collected in Iceland near the source, allowed the reconstruction of the $\mathrm{PM}_{10}$ mass contributed by the volcanic plume at CMN. The calculated contribution ranged from 7.3 to $9.5 \mu \mathrm{g} \mathrm{m}^{-3}$, corresponding respectively to 32 to $41 \%$ of the reconstructed $\mathrm{PM}_{10}$ mass.

To our knowledge, no similar estimates were provided for other sites south of the Alps, though plume observations were reported over Spain, Slovenia and Greece.

The impact of the volcanic plume at CMN did not strongly affect the air quality at ground level. In fact, $\mathrm{PM}_{2.5}$ and $\mathrm{PM}_{10}$ data of the Regional Agency for Environmental Protection in the urban area of Bologna and at the lowland site of San Pietro Capofiume did not evidence any significant increase in aerosol mass during the April episode, but did display an enhancement of about $10 \mu \mathrm{g} \mathrm{m}^{-3}$ during the May episode, though this latter cannot be completely attributed to a volcanic origin. This emphasises the importance of aerosol chemical analysis in distinguishing volcanic influences from other factors and processes, and confirms that the high altitude site of CMN, due to its remote, mostly non-PBL-influenced location, is an appropriate observation site, not only for characterising the regional background but also for identifying air-mass transport effects and isolating long-range transport phenomena, such as the volcanic plume transport over Southern Europe.

Acknowledgements. NOAA Air Resources Laboratory is acknowledged for providing the HYSPLIT trajectories (http://ready.arl. noaa.gov/HYSPLIT.php) used in this study.

The "O. Vittori" station at Mt. Cimone is supported by the National Research Council of Italy and the Italian Ministry of Education, University and Research throughout the Project of Interest NextData. The authors are grateful to the staff employed at the station for the technical support.

Thanks are also due to the Regional Agency for Prevention and Environment, Emilia-Romagna, for the provision of $\mathrm{PM}_{10}$ and $\mathrm{PM}_{2.5}$ data in Bologna and San Pietro Capofiume.

Edited by: A. Petzold

\section{References}

Aiken, A. C., DeCarlo, P. F., Kroll, J. H., Worsnop, D. R., Huffman, J. A., Docherty, K. S., Ulbrich, I. M., Mohr, C., Kimmel, J. R., Sueper, D., Sun, Y., Zhang, Q., Trimborn, A., Northway, M., Ziemann, P. J., Canagaratna, M. R., Onasch, T. B., Alfarra, M. R., Prevot, A. S. H., Dommen, J., Duplissy, J., Metzger, A., Baltensperger, U., and Jimenez, J. L.: O/C and OM/OC Ratios of Primary, Secondary, and Ambient Organic Aerosols with HighResolution Time-of-Flight Aerosol Mass Spectrometry, Environ. Sci. Technol., 42, 4478-4485, doi:10.1021/es703009q, 2008.

Allen, A. G., Baxter, P. J., and Ottley, C. J.: Gas and particle emissions from Soufriere Hills Volcano, Montserrat,West Indies: Characterization and health hazard assessment, B. Volcanol., 62, 8-19, 2000.

Andersson, S. M., Martinsson, B. G., Friberg, J., Brenninkmeijer, C. A. M., Rauthe-Schöch, A., Hermann, M., van Velthoven, P. F. J., and Zahn, A.: Composition and evolution of volcanic aerosol from eruptions of Kasatochi, Sarychev and Eyjafjallajökull in 2008-2010 based on CARIBIC observations, Atmos. Chem. Phys., 13, 1781-1796, doi:10.5194/acp-13-1781-2013, 2013.

Ansmann, A., Tesche, M., Groß, S., Freudenthaler, V., Seifert, P., Hiebsch, A., Schmidt, J., Wandinger, U., Mattis, I., Müller, D., and Wiegner M.: The 16 April 2010 major volcanic ash plume over central Europe: EARLINET lidar and AERONET photometer observations at Leipzig and Munich, Germany, Geophys. Res. Lett., 37, L13810, doi:10.1029/2010GL043809, 2010.

Asmi, A., Wiedensohler, A., Laj, P., Fjaeraa, A.-M., Sellegri, K., Birmili, W., Weingartner, E., Baltensperger, U., Zdimal, V., Zikova, N., Putaud, J.-P., Marinoni, A., Tunved, P., Hansson, H.C., Fiebig, M., Kivekäs, N., Lihavainen, H., Asmi, E., Ulevicius, V., Aalto, P. P., Swietlicki, E., Kristensson, A., Mihalopoulos, N., Kalivitis, N., Kalapov, I., Kiss, G., de Leeuw, G., Henzing, B., Harrison, R. M., Beddows, D., O’Dowd, C., Jennings, S. G., Flentje, H., Weinhold, K., Meinhardt, F., Ries, L., and Kulmala, M.: Number size distributions and seasonality of submicron particles in Europe 2008-2009, Atmos. Chem. Phys., 11, 5505-5538, doi:10.5194/acp-11-5505-2011, 2011.

Bagnato, E., Aiuppa, A., Bertagnini, A., Bonadonna, C., Cioni, R., Pistolesi, M., Pedone, M., and Hoskuldsson, A.: Scavenging of sulphur, halogens and trace metals by volcanic ash: The 2010 Eyjafjallajökull eruption, Geochim. Cosmochim. Ac., 103, 138160, 2013.

Balis, D., Giannakaki, E., Mamouri, R. E., Kokkalis, P., Papayannis, A., and Tsaknakis, G.: EARLINET observations of the Eyjafjallajökull ash plume over Greece. Proc. SPIE 7832, Lidar Technologies, Techniques, and Measurements for Atmospheric Remote Sensing VI, 783200 (October, 26 2010), doi:10.1117/12.868941, 2010.

Beeston, M., Grgić, I., van Elteren, J. T., Iskra, I., Kapun, G., and Močnik, G.: Chemical and morphological characterization of aerosol particles at Mt. Krvavec, Slovenia, during the Eyjafjallajökull Icelandic volcanic eruption, Environ. Sci. Pollut. R., 19, 235-243, doi:10.1007/s11356-011-0563-8, 2012.

Belosi, F., Santachiara, G., and Prodi, F.: Eyjafjallajökull volcanic eruption: Ice Nuclei and particle characterization, Atmospheric and Climate Sciences, 1, 48-54, doi:10.4236/acs.2011.12005, 2011. 
Bonasoni, P., Evangelisti, F., Bonafè, U., Ravegnani, F., Calzolari, F., Stohl, A., Tositti, L., Tubertini, O., and Colombo, T.: Stratospheric ozone intrusion episodes recorded at Mt. Cimone during the VOTALP project: Case studies, Atmos. Environ., 34, 13551365, 2000.

Boulon, J., Sellegri, K., Hervo, M., and Laj, P.: Observations of nucleation of new particles in a volcanic plume, P. Natl. Acad. Sci. USA, 108, 12223-12226, doi:10.1073/pnas.1104923108, 2011.

Bukowiecki, N., Zieger, P., Weingartner, E., Jurányi, Z., Gysel, M., Neininger, B., Schneider, B., Hueglin, C., Ulrich, A., Wichser, A., Henne, S., Brunner, D., Kaegi, R., Schwikowski, M., Tobler, L., Wienhold, F. G., Engel, I., Buchmann, B., Peter, T., and Baltensperger, U.: Ground-based and airborne in-situ measurements of the Eyjafjallajökull volcanic aerosol plume in Switzerland in spring 2010, Atmos. Chem. Phys., 11, 10011-10030, doi:10.5194/acp-11-10011-2011, 2011.

Calzolai, G., Chiari, M., García Orellana, I., Lucarelli, F., Migliori, A., Nava, S., and Taccetti, F.: The new external beam facility for environmental studies at the Tandetron accelerator of LABEC, Nucl. Instrum. Meth. B, 249, 928-931, 2006.

Calzolai, G., Chiari, M., Lucarelli, F., Nava, S., and Portarena, S.: Proton induced $\gamma$-ray emission yields for the analysis of light elements in aerosol samples in an external beam set-up, Nucl. Instrum. Meth. B, 268, 1540-1545, 2010.

Campanelli, M., Estelles, V., Smyth, T., Tomasi, C., MartìnezLozano, M. P., Claxton, B., Muller, P., Pappalardo, G.,. Pietruczuk, A, Shanklin, J., Colwell, S., Wrench, C., Lupi, A., Mazzola, M., Lanconelli, C., Vitale, V., Congeduti, F., Dionisi, D., Cardillo, F., Cacciani, M., Casasanta, G., and Nakajima, T.: Monitoring of Eyjafjallajökull volcanic aerosol by the new European Skynet Radiometers (ESR) network, Atmos. Environ., 48, 33-45, doi:10.1016/j.atmosenv.2011.09.070, 2012.

Canepari, S., Cardarelli, E., Pietrodangelo, A., and Giuliano, A.: Determination of metals, metalloids and non-volatile ions in airborne particulate matter by a new two-step sequential leaching procedure. Part A: experimental design and optimization, Talanta, 69, 581-587, doi:10.1016/j.talanta.2005.10.023, 2006.

Canepari, S., Astolfi, M. L., Moretti, S., and Curini, R.: Comparison of extracting solutions for elemental fractionation in airborne particulate matter, Talanta, 82, 834-844, doi:10.1016/j.talanta.2010.05.068, 2010.

Carbone, C., Decesari, S., Mircea, M., Giulianelli, L., Finessi, E., Rinaldi, M., Fuzzi, S., Marinoni, A., Duchi, R., Perrino, C., Sargolini, T., Vardè, M., Sprovieri, F., Gobbi, G. P., Angelini, F., and Facchini, M. C.: Size-resolved aerosol chemical composition over the Italian Peninsula during typical summer and winter conditions, Atmos. Environ. 44, 5269-5278, doi:10.1016/j.atmosenv.2010.08.008, 2010.

Colette, A., Favez, O., Meleux, F., Chiappini, L., Haeffelin, M., Morille, Y., Malherbe, L. , Papin, A., Bessagnet, B., Menut, L., Leoz, E., and Rouill, L.: Assessing in near real time the impact of the April 2010 Eyjafjallajökull ash plume on air quality, Atmos. Environ., 45, 1217-1221, doi:10.1016/j.atmosenv.2010.09.064, 2011.

Cristofanelli, P., Bonasoni, P., Carboni, G., Calzolari, F., Casarola, L., Zauli Sajani, S., and Santaguida, R.: Anomalous high ozone concentrations recorded at a high mountain station in Italy in summer 2003, Atmos. Environ., 41, 1383-1394, doi:10.1016/j.atmosenv.2006.10.017, 2007.
Cristofanelli, P., Marinoni, A., Arduini, J., Bonafè, U., Calzolari, F., Colombo, T., Decesari, S., Duchi, R., Facchini, M. C., Fierli, F., Finessi, E., Maione, M., Chiari, M., Calzolai, G., Messina, P., Orlandi, E., Roccato, F., and Bonasoni, P.: Significant variations of trace gas composition and aerosol properties at Mt. Cimone during air mass transport from North Africa - contributions from wildfire emissions and mineral dust, Atmos. Chem. Phys., 9, 4603-4619, doi:10.5194/acp-9-4603-2009, 2009.

Cristofanelli, P., Fierli, F., Marinoni, A., Calzolari, F., Duchi, R., Burkhart, J., Stohl, A., Maione, M., Arduini, J., and Bonasoni, P.: Influence of biomass burning and anthropogenic emissions on ozone, carbon monoxide and black carbon at the Mt. Cimone GAW-WMO global station (Italy, $2165 \mathrm{~m}$ a.s.1.), Atmos. Chem. Phys., 13, 15-30, doi:10.5194/acp-13-15-2013, 2013.

Draxler, R. R. and Rolph, G. D.: HYSPLIT (HYbrid Single-Particle Lagrangian Integrated Trajectory) Model access via NOAA ARL READY Website, http://ready.arl.noaa.gov/HYSPLIT.php (last access: June 2013), Silver Spring, MD, 2013.

Emeis, S., Forkel, R., Junkermann, W., Schäfer, K., Flentje, H., Gilge, S., Fricke, W., Wiegner, M., Freudenthaler, V., Groß, S., Ries, L., Meinhardt, F., Birmili, W., Münkel, C., Obleitner, F., and Suppan, P.: Measurement and simulation of the 16/17 April 2010 Eyjafjallajökull volcanic ash layer dispersion in the northern Alpine region, Atmos. Chem. Phys., 11, 2689-2701, doi:10.5194/acp-11-2689-2011, 2011.

Fischer, H., Kormann, R., Klüpfel, T., Gurk, Ch., Königstedt, R., Parchatka, U., Mühle, J., Rhee, T. S., Brenninkmeijer, C. A. M., Bonasoni, P., and Stohl, A.: Ozone production and trace gas correlations during the June 2000 MINATROC intensive measurement campaign at Mt. Cimone, Atmos. Chem. Phys., 3, 725-738, doi:10.5194/acp-3-725-2003, 2003.

Flentje, H., Claude, H., Elste, T., Gilge, S., Köhler, U., PlassDülmer, C., Steinbrecht, W., Thomas, W., Werner, A., and Fricke, W.: The Eyjafjallajökull eruption in April 2010 - detection of volcanic plume using in-situ measurements, ozone sondes and lidar-ceilometer profiles, Atmos. Chem. Phys., 10, 10085-10092, doi:10.5194/acp-10-10085-2010, 2010.

Formenti, P., Nava, S., Prati, P., Chevaillier, S., Klaver, A., Lafon, S., Mazzei, F., Calzolai, G., and Chiari, M.: Self-attenuation artifacts and correction factors of light element measurements by X-ray analysis: Implication for mineral dust composition studies, J. Geophys. Res. 115, D01203, doi:10.1029/2009JD012701, 2010.

Gelencsér, A.: Carbonaceous Aerosol, Atmospheric and Oceangraphic Science Library Series, Vol. 30, Springer, New York, 2004.

Gislason, S. R., Hassenkam, T., Nedel, S., Bovet, N., Eiriksdottir, E. S., Alfredsson, H. A., Hem, C. P., Balogh, Z. I., Dideriksen, K., Oskarsson, N., Sigfusson, B., Larsen, G., and Stipp, S. L. S.: Characterization of Eyjafjallajökull volcanic ash particles and a protocol for rapid risk assessment, P. Natl. Acad. Sci. USA, 108, 18, 7307-7312, doi:10.1073/pnas.1015053108, 2011.

Hervo, M., Quennehen, B., Kristiansen, N. I., Boulon, J., Stohl, A., Fréville, P., Pichon, J.-M., Picard, D., Labazuy, P., Gouhier, M., Roger, J.-C., Colomb, A., Schwarzenboeck, A., and Sellegri, K.: Physical and optical properties of 2010 Eyjafjallajökull volcanic eruption aerosol: ground-based, Lidar and airborne measurements in France, Atmos. Chem. Phys., 12, 17211736, doi:10.5194/acp-12-1721-2012, 2012. 
Hinkley, T. K., Le Cloarec, M. F., and Lambert, G.: Fractionation of families of major, minor, and trace metals across the melt-vapor interface in volcanic exhalations, Geochim. Cosmochim. Ac., 58, 3255-3263, doi:10.1016/0016-7037(94)90053-1, 1994.

Khlystov, A., Stanier, C., and Pandis, S. N.: An Algorithm for Combining Electrical Mobility and Aerodynamic Size Distributions Data when Measuring Ambient Aerosol, Aerosol Sci. Tech., 38, 229-238. doi:10.1080/02786820390229543, 2004.

Koltay, E., Rajta, I., Morales, J. R., Borbély-Kiss, I., and Kiss, Á. Z.: Characterization of individual aerosol particles from the eruption of Lonquimay volcano, Chile, Nucl. Instrum. Meth. B, 150, 375383, 1999

Krabbe, S., Lutz-Holzhauer, C., and Stoll, S.: Ausbruch des Eyjafjallajökull im April 2010, Auswirkungen auf die Feinstaubkonzentrationen in Baden-Württemberg, LUBW Landesanstalt für Umwelt, Messungen und Naturschutz BadenWürttemberg, Karlsruhe, Germany, 2010.

Lettino, A., Caggiano, R., Fiore, S., Macchiato, M., Sabia, S., and Trippetta, S.: Eyjafjallajökull volcanic ash in southern Italy, Atmos. Environ., 48, 97-103, 2012.

Madonna, F., Amodeo, A., D’Amico, G., Mona, L., and Pappalardo, G.: Observation of nonspherical ultragiant aerosol using a microwave radar, Geophys. Res. Lett., 37, L21814, doi:10.1029/2010GL044999, 2010.

Marenco, F., Bonasoni, P., Calzolari, F., Ceriani, M., Chiari, M., Cristofanelli, P., D’Alessandro, A., Fermo, P., Lucarelli, F., Mazzei, F., Nava, S., Piazzalunga, A., Prati, P., Valli. G., and Vecchi, R.: Characterization of atmospheric aerosols at Monte Cimone, Italy, during summer 2004: source apportionment and transport mechanisms, J. Geophys. Res., 111, D24202, doi:10.1029/2006JD007145, 2006.

Marinoni, A., Cristofanelli, P., Calzolari, F., Roccato, F., Bonafè, U., and Bonasoni, P.: Continuous measurements of aerosol physical parameters at the Mt. Cimone GAW Station (2165 m a.s.l., Italy), Sci. Total Environ., 391, 241-251, doi:10.1016/j.scitotenv.2007.10.004, 2008.

Mather, T. A.: Volcanism and the atmosphere: the potential role of the atmosphere in unlocking the reactivity of volcanic emissions, Philos. Trans. A Math. Phys. Eng. Sci., 366, 4581-4595, doi:10.1098/rsta.2008.0152, 2008.

Mather, T. A., Pyle, D. M., and Oppenheimer, C.: Tropospheric volcanic aerosol, in: Volcanism and the Earth's Atmosphere, Geophysical Monograph 139 Copyright 2003 by the American Geophysical Union, doi:10.1029/139GM12, 2003.

Mather, T. A., McCabe, J. R., Rai, V. K., Thiemens, M. H., Pyle, D. M., Heaton, T. H. E., Sloane, H. J., and Fern, G. R.: Oxygen and sulfur isotopic composition of volcanic sulfate aerosol at the point of emission, J. Geophys. Res., 111, D18205, doi:10.1029/2005JD006584, 2006.

Mona, L., Amodeo, A., D’Amico, G., Giunta, A., Madonna, F., and Pappalardo, G.: Multi-wavelength Raman lidar observations of the Eyjafjallajökull volcanic cloud over Potenza, southern Italy, Atmos. Chem. Phys., 12, 2229-2244, doi:10.5194/acp-12-22292012, 2012.

Moune, S., Gauthier, P.-J., Gislason, S. R., and Sigmarsson, O.: Trace element degassing and enrichment in the eruptive plume of the 2000 eruption of Hekla volcano, Iceland, Geochim. Cosmochim. Ac. 70, 461-479, 2006.
O’Dowd, C., Ceburnis, D., Ovadnevaite, J., Martucci, G., Bialek, J., Monahan, C., Berresheim, H., Vaishya, A., Grigas, T., Jennings, S. G., McVeigh, P., Varghese, S., Flanagan, R., Martin, D., Moran, E., Lambkin, K., Semmler, T., Perrino, C., and McGrath, R.: The Eyjafjallajökull ash plume - Part I: Physical, chemical and optical characteristics, Atmos. Environ., 48, 129-142, doi:10.1016/j.atmosenv.2011.07.004, 2012.

Papayannis, A., Mamouri, R.E., Amiridis, V., Giannakaki, E., Veselovskii, I., Kokkalis, P., Tsaknakis, G., Balis, D., Kristiansen, N. I., Stohl, A., Korenskiy, M., Allakhverdiev, K., Huseyinoglu, M. F., and Baykara, T.: Optical properties and vertical extension of aged ash layers over the Eastern Mediterranean as observed by Raman lidars during the Eyjafjallajökull eruption in May 2010, Atmos. Environ., 48, 56-65, doi:10.1016/j.atmosenv.2011.08.037, 2012.

Pappalardo, G., Mona, L., D’Amico, G., Wandinger, U., Adam, M., Amodeo, A., Ansmann, A., Apituley, A., Alados Arboledas, L., Balis, D., Boselli, A., Bravo-Aranda, J. A., Chaikovsky, A., Comeron, A., Cuesta, J., De Tomasi, F., Freudenthaler, V., Gausa, M., Giannakaki, E., Giehl, H., Giunta, A., Grigorov, I., Groß, S., Haeffelin, M., Hiebsch, A., Iarlori, M., Lange, D., Linné, H., Madonna, F., Mattis, I., Mamouri, R.-E., McAuliffe, M. A. P., Mitev, V., Molero, F., Navas-Guzman, F., Nicolae, D., Papayannis, A., Perrone, M. R., Pietras, C., Pietruczuk, A., Pisani, G., Preißler, J., Pujadas, M., Rizi, V., Ruth, A. A., Schmidt, J., Schnell, F., Seifert, P., Serikov, I., Sicard, M., Simeonov, V., Spinelli, N., Stebel, K., Tesche, M., Trickl, T., Wang, X., Wagner, F., Wiegner, M., and Wilson, K. M.: Four-dimensional distribution of the 2010 Eyjafjallajökull volcanic cloud over Europe observed by EARLINET, Atmos. Chem. Phys., 13, 4429-4450, doi:10.5194/acp-13-4429-2013, 2013.

Perrino, C., Canepari, S., Cardarelli, E., Catrambone, M., and Sargolini, T.: Inorganic constituents of urban air pollution in the Lazio region (Central Italy), Environ. Monit. Assess., 128, 133151, doi:10.1007/s10661-006-9269-7, 2007.

Perrone, M. R., De Tomasi, F., Stohl, A., and Kristiansen, N. I.: Integration of measurements and model simulations to characterize Eyjafjallajökull volcanic aerosols over south-eastern Italy, Atmos. Chem. Phys., 12, 10001-10013, doi:10.5194/acp-1210001-2012, 2012.

Petzold, A. and Schönlinner, M.: Multi-angle absorption photometry - a new method for the measurement of aerosol light absorption and atmospheric black carbon, J. Aerosol Sci., 35, 421-441, doi:10.1016/j.jaerosci.2003.09.005, 2004.

Petzold, A., Kramer, H., and Schönlinner, M.: Continuous Measurement of Atmospheric Black Carbon Using a Multi-angle Absorption Photometer, Environ. Sci. Pollut. R., 4, 78-82, 2002.

Pope, C. A.: Epidemiology of Fine Particulate Air Pollution and $\mathrm{Hu}-$ man Health: Biologic Mechanisms and Who's at Risk?, Environ. Health Persp., 108, 712-723, 2000.

Putaud, J.-P., Van Dingenen, R., Dell'Acqua, A., Raes, F., Matta, E., Decesari, S., Facchini, M. C., and Fuzzi, S.: Size-segregated aerosol mass closure and chemical composition in Monte $\mathrm{Ci}$ mone (I) during MINATROC, Atmos. Chem. Phys., 4, 889-902, doi:10.5194/acp-4-889-2004, 2004.

Rauthe-Schöch, A., Weigelt, A., Hermann, M., Martinsson, B. G., Baker, A. K., Heue, K.-P., Brenninkmeijer, C. A. M., Zahn, A., Scharffe, D., Eckhardt, S., Stohl, A., and van Velthoven, P. F. J.: CARIBIC aircraft measurements of Eyjafjallajökull volcanic 
clouds in April/May 2010, Atmos. Chem. Phys., 12, 879-902, doi:10.5194/acp-12-879-2012, 2012.

Revuelta, M. A., Sastre, M., Fernández, A. J., Martín, L., García, R., Gómez-Moreno, F. J., Artíñano, B., Pujadas, M., and Molero, F.: Characterization of the Eyjafjallajökull volcanic plume over the Iberian Peninsula by lidar remote sensing and ground-level data collection, Atmos. Environ., 4, 46-55, doi:10.1016/j.atmosenv.2011.05.033, 2012.

Rose, W. I., Chuan, R. L., Giggenbach, W. F., Kyle, P. R., and Symonds, R. B.: Rates of sulfur dioxide and particle emissions from White Island volcano, New Zealand, and an estimate of the total flux of major gaseous species, B. Volcanol., 48, 181-188, 1986.

Rossini, P., Molinaroli, E., De Falco, G., Fiesoletti, F., Papa, S., Pari, E., Renzulli, A., Tentoni, P., Testoni, A., Valentini, L., and Matteucci, G.: April-May 2010 Eyjafjallajökull volcanic fallout over Rimini, Italy, Atmos. Environ., 48, 122-128, doi:10.1016/j.atmosenv.2011.05.018, 2012.

Schäfer, K., Thomas, W., Peters, A., Ries, L., Obleitner, F., Schnelle-Kreis, J., Birmili, W., Diemer, J., Fricke, W., Junkermann, W., Pitz, M., Emeis, S., Forkel, R., Suppan, P., Flentje, H., Gilge, S., Wichmann, H. E., Meinhardt, F., Zimmermann, R., Weinhold, K., Soentgen, J., Münkel, C., Freuer, C., and Cyrys, J.: Influences of the 2010 Eyjafjallajökull volcanic plume on air quality in the northern Alpine region, Atmos. Chem. Phys., 11, 8555-8575, doi:10.5194/acp-11-8555-2011, 2011.

Schleicher, N., Kramar, U., Dietze, V., Kaminski, U., and Norra, S.: Geochemical characterization of single atmospheric particles from the Eyjafjallajökull volcano eruption event collected at ground-based sampling sites in Germany, Atmos. Environ. 48, 113-121, doi:10.1016/j.atmosenv.2011.05.034, 2012.

Schumann, U., Weinzierl, B., Reitebuch, O., Schlager, H., Minikin, A., Forster, C., Baumann, R., Sailer, T., Graf, K., Mannstein, H., Voigt, C., Rahm, S., Simmet, R., Scheibe, M., Lichtenstern, M., Stock, P., Rüba, H., Schäuble, D., Tafferner, A., Rautenhaus, M., Gerz, T., Ziereis, H., Krautstrunk, M., Mallaun, C., Gayet, J.F., Lieke, K., Kandler, K., Ebert, M., Weinbruch, S., Stohl, A., Gasteiger, J., Groß, S., Freudenthaler, V., Wiegner, M., Ansmann, A., Tesche, M., Olafsson, H., and Sturm, K.: Airborne observations of the Eyjafjalla volcano ash cloud over Europe during air space closure in April and May 2010, Atmos. Chem. Phys., 11, 2245-2279, doi:10.5194/acp-11-2245-2011, 2011.
Sigmundsson, F., Hreinsdóttir, S., Hooper, A., Arnadóttir, T., Pedersen, R., Roberts, M. J., Oskarsson, N., Auriac, A., Decriem, J., Einarsson, P., Geirsson, H., Hensch, M., Ofeigsson, B. G., Sturkell, E., Sveinbjörnsson, H., and Feig, K. L.: Intrusion triggering of the 2010 Eyjafjallajökull explosive eruption, Nature, 468, 426-430, doi:10.1038/nature09558, 2010.

Stohl, A., Prata, A. J., Eckhardt, S., Clarisse, L., Durant, A., Henne, S., Kristiansen, N. I., Minikin, A., Schumann, U., Seibert, P., Stebel, K., Thomas, H. E., Thorsteinsson, T., Tørseth, K., and Weinzierl, B.: Determination of time- and height-resolved volcanic ash emissions and their use for quantitative ash dispersion modeling: the 2010 Eyjafjallajökull eruption, Atmos. Chem. Phys., 11, 4333-4351, doi:10.5194/acp-11-4333-2011, 2011.

Symonds, R. B., Rose, W. I., Reed, M. H., Litchte, F. E., and Finnegan, D. L.: Volatilisation, transport and sublimation of metallic and non-metallic elements in high temperature gases at Merapi Volcano, Indonesia, Geochim. Cosmochim. Ac., 51, 2083-2101, 1987.

Trickl, T., Giehl, H., Jäger, H., and Vogelmann, H.: 35 yr of stratospheric aerosol measurements at Garmisch-Partenkirchen: from Fuego to Eyjafjallajökull, and beyond, Atmos. Chem. Phys., 13, 5205-5225, doi:10.5194/acp-13-5205-2013, 2013.

Von Glasow, R., Bobrowski, N., and Kern, C.: The effects of volcanic eruptions on atmospheric chemistry, Chem. Geol., 263, 131-142, doi:10.1016/j.chemgeo.2008.08.020, 2009.

Wiedensohler, A., Birmili, W., Nowak, A., Sonntag, A., Weinhold, K., Merkel, M., Wehner, B., Tuch, T., Pfeifer, S., Fiebig, M., Fjäraa, A. M., Asmi, E., Sellegri, K., Depuy, R., Venzac, H., Villani, P., Laj, P., Aalto, P., Ogren, J. A., Swietlicki, E., Williams, P., Roldin, P., Quincey, P., Hüglin, C., Fierz-Schmidhauser, R., Gysel, M., Weingartner, E., Riccobono, F., Santos, S., Grüning, C., Faloon, K., Beddows, D., Harrison, R., Monahan, C., Jennings, S. G., O’Dowd, C. D., Marinoni, A., Horn, H.-G., Keck, L., Jiang, J., Scheckman, J., McMurry, P. H., Deng, Z., Zhao, C. S., Moerman, M., Henzing, B., de Leeuw, G., Löschau, G., and Bastian, S.: Mobility particle size spectrometers: harmonization of technical standards and data structure to facilitate high quality long-term observations of atmospheric particle number size distributions, Atmos. Meas. Tech., 5, 657-685, doi:10.5194/amt5-657-2012, 2012.

Witham, C. S., Oppenheimer, C., and Horwel, C. J.: Volcanic ash leachates: a review and recommendations for sampling methods, J. Volcanol. Geoth. Res. 141, 299-326, 2005. 